\title{
KONTROLOWANIE ZAGRANICZNYCH I ZAKORDONOWYCH CZASOPISM POLSKICH PRZEZ CENZURĘ ROSYJSKĄ W LATACH 1865-1904
}

Stosunek cenzury rosyjskiej do sprowadzanych czasopism polskich. Wielkość i struktura importu. Reakcje importerów na decyzje o całkowitym zakazie lub o warunkowym dopuszczeniu do rozpowszechniania danego tytułu: rezygnacja z prenumeraty, ponawianie prób. Treść negatywnych uzasadnień cenzorskich. Przyczyny nikłej obecności pism importowanych w obiegu królewiackim.

SŁOWA KLUCZOWE: carska cenzura zagraniczna, granice wolności słowa — zabór rosyjski — XIX wiek, czasopisma polskojęzyczne — import — zabór rosyjski, czasopisma polskojęzyczne - cenzurowanie, cenzurowanie czasopism - typy kwestionowanych treści - uzasadnienia cenzorskie

Spośród publikacji ukazujących się w Rosji szczególnie surowo cenzurowano wszelkie publikacje periodyczne ${ }^{1}$. Chodziło o ograniczenie wiedzy mieszkańców na temat tego, co wykraczało poza obszar ich spraw prywatnych, o utrudnianie kształtowania się w społeczeństwie niekontrolowanych więzi ponadlokalnych, a w konsekwencji — swobodnego funkcjonowania niezależnej opinii publicz-

${ }^{1}$ Oczywiście w porównaniu z produkcją książkową (zwłaszcza z publikacjami specjalistycznymi). Jednak w zestawieniu z okresem wcześniejszym sytuacja prasy była po 1865 roku znacznie lepsza, choć głównie w obu stolicach. Pisał o tym między innymi Marek Tobera (Cenzura prasy w Cesarstwie Rosyjskim na przełomie XIX i XX w., [w:] Piśmiennictwo — systemy kontroli-obiegi alternatywne, pod red. J. Kosteckiego, A. Brodzkiej, T. 1, Warszawa 1992, s. 175-223). Problem ten jest stałym przedmiotem zainteresowania badaczy rosyjskich, zwłaszcza w ostatnich dekadach. Niestety w ich pracach problemy funkcjonowania prasy polskiej zajmują miejsce marginalne. 
nej, która mogłaby się zwrócić przeciwko władzy. Podobne cele przyświecały kontrolowaniu — potencjalnie niebezpiecznych — periodyków importowanych, zwłaszcza wydawanych w językach, którymi posługiwały się na co dzień duże grupy ludności zamieszkujące imperium, a więc nie tylko w rosyjskim, ale także w polskim i jidysz. W wypadku publikacji w języku polskim chodziło przy tym o to, by „odrąbać Polaków swoich od austriackich i pruskich”2.

Należy przypuszczać, że od początku lat 70. do końca badanego okresu około $80 \%$ wszelkich — nieznanych wcześniej cenzurze $e^{3}$ - importowanych publikacji w języku polskim rozpatrywali urzędnicy zatrudnieni w Warszawskim Komitecie Cenzury (dalej: WKC) ${ }^{4}$. Powstał on na mocy ogłoszonego 1 stycznia 1870 roku Ukazu Najwyższego z 17 (29) września 1869 r. o ustanowieniu $w$ miejsce istniejacego $w$ Warszawie komitetu cenzury $i$ wydziatu prasy periodycznej — „Warszawskiego komitetu cenzury”, i oddaniu takowego pod zarzad ministerstwa spraw wewnętrznych ${ }^{5}$. „Bezpośrednie zwierzchnictwo nad Komitetem sprawował »główny naczelnik kraju«, tj. najpierw namiestnik, a od $1874 \mathrm{r}$. generał-gubernator warszawski" ${ }^{\text {. }}$ W odróżnieniu od niemal wszystkich innych Komitetów działających w Cesarstwie WKC miał — zgodnie z przywoływanym dekretem — charakter wielofunkcyjny ${ }^{7}$, kontrolował bowiem zarówno publikacje miejscowe, jak i importowane, druki zwarte, jak i periodyczne, a także sztuki teatralne (poza napisanymi w języku rosyjskim). Dopiero gdy 23 maja 1896 roku

2 [S. Krzemiński], Dwadzieścia pięć lat Rosyi w Polsce (1863-1898). Zarys historyczny, Lwów 1892, s. 191. W całym artykule w cytowanych tekstach w języku polskim celowo zachowuję ortografię i interpunkcję oryginału. Wszelkie dopiski w przytaczanych tekstach (zarówno polskich, jak i tłumaczonych), znajdujące się w nawiasach kwadratowych, pochodzą ode mnie. Zob. też przypis 41 .

${ }^{3}$ Gdy publikację próbowano sprowadzić po raz kolejny, władze odwoływały się do decyzji wydanej wcześniej. Zmiany werdyktów zdarzały się w zasadzie dopiero po 1906 roku.

4 J. Kostecki, Trudny proces przenikania. Carska cenzura zagraniczna wobec importu publikacji w języku polskim w latach 1865-1904, Warszawa 2011, s. 57. Zob. też idem, Rosyjska praktyka kontroli piśmiennictwa - uzasadnienia negatywnych decyzji cenzorskich $w 2$. połowie XIX wieku. Próba typologii, [w:] Literatura w granicach prawa (XIX-XX w.), pod red. K. Budrowskiej, E. Dąbrowicz, M. Lula, Warszawa 2013, s. 109. WKC przetrwał do 26 kwietnia 1906 roku, kiedy to przemianowano go (jak kilka innych w Cesarstwie) na Komitet do spraw Druku (J. Kostecki, Warszawski Komitet Cenzury w latach 1870-1906, [w:] Ksią̇ka zawsze obecna. Prace ofiarowane Krzysztofowi Migoniowi, pod. red. M. Skalskiej-Zlat, Wrocław 2010, s. 289).

5 „Dziennik Praw” 69, 1869, nr 239, s. 439. To w strukturze Ministerstwa Spraw Wewnętrznych działał Zarząd Główny do spraw Druku i podległy mu Komitet Cenzury Zagranicznej (od 1894 roku — Centralny Komitet Cenzury Zagranicznej) — oba w Petersburgu.

${ }^{6}$ F. Ramotowska, Sto lat „,cenzury rzadowej” pod zaborem rosyjskim (1815-1915) — podstawy normatywne, instrumenty wykonawcze, [w:] Piśmiennictwo - systemy kontroli..., s. 166.

${ }^{7}$ Poza nim charakter wielofunkcyjny miał jeszcze tylko Kaukaski Komitet Cenzury w Tyflisie (J. Kostecki, Carski system cenzury zagranicznej w XIX wieku, [w:] Niewygodne dla władzy. Ograniczanie wolności słowa na ziemiach polskich w XIX i XX wieku. Zbiór studiów, pod red. D. Degen, J. Gzelli, Toruń 2010, s. 20-21, 24). 
Mikołaj II zatwierdził uchwałę Rady Państwa, która między innymi uchylała treść uwagi I do art. 187 ustawy cenzuralnej, nawiązującej do owego dekretu i mówiącej między innymi, że „Do kompetencji Warszawskiego Komitetu Cenzury należy także cenzura wydawnictw periodycznych prenumerowanych za granicą za pośrednictwem Warszawskiego Urzędu Pocztowego [...]”, , w styczniu 1897 roku „oficjalnie powstała cenzura zagranicznych gazet i czasopism przy Warszawskim Urzędzie Pocztowym [...] [do którego] przeniesiono cenzorów z gubernialnego

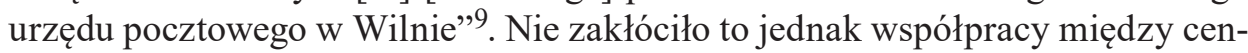
zurą pocztową a zagraniczną, gdyż zgodnie z uwagą I do art. 191 cytowanej już ustawy „Odrębna cenzura powołana przy urzędach pocztowych, obowiązana jest co miesiąc informować [Centralny] Komitet Cenzury Zagranicznej, które numery czasopism i gazet zagranicznych zatrzymała" 10 . Dane te trafiały z kolei do ogólnych miesięcznych spisów publikacji zarówno dopuszczonych (w całości lub w części), jak i w ogóle niedopuszczonych do rozpowszechniania, rozsyłanych do wszystkich placówek zajmujących się kontrolą publikacji.

Owe spisy stanowią jedno z dwóch głównych źródeł wykorzystanych w prezentowanej pracy ${ }^{11}$. Drugie to zachowane w Archiwum Głównym Akt Dawnych

${ }^{8}$ Ustav o cenzure i pečati, „Svod Zakonov Rossijskoj imperii”, izd. 1890 g., t. 14, Sanktpeterburg b.r., s. 29. Wszystkie tłumaczenia tekstów rosyjskich własne.

9 Cenzory Rossijskoj imperii konec XVIII-načalo XX veka. Biobibliografičeskij spravočnik, red. koll. V.R. Firsov [et al.], avt. koll. O.Û. Abakumov [et al.], Sankt-Peterburg 2013, s. 55. Zob. też W.S. Izmozik, Počtovaâ cenzura v Rossii do 1917 g.: oficialnaâ i tajnaâ, [w:] Cenzura i dostup k informacii: istoriâ i sovremennost'. Tezisy dokladov meždunarodnoj naučnoj konferencii, Sankt-Peterburg, 16-18 marta 2005 g. Sankt-Peterburg 2005, s. 29; Ministerstvo vnutrennih dèl. 1802-1902. Istoričeskij očerk, priloženie 2: počta i telegraf v XIX stoletii, Sankt-Peterburg 1901, s. 119; F. Ramotowska, op. cit., s. 170. Od 1897 roku cała cenzura pocztowa podlegała już więc Głównemu Zarządowi Poczt i Telegrafów. Nawiasem mówiąc, mam wątpliwości, czy omawiany dekret konsekwentnie wprowadzono w życie. Po pierwsze, pod uzasadnieniami wszystkich decyzji odnoszących się do czasopism polskojęzycznych rozpatrywanych w latach 1897, 1899 i 1903 (protokoły z lat 1898, 1900-1902 nie zachowały się) widnieją nazwiska cenzorów zatrudnionych wówczas w WKC. Po drugie, spośród 20 urzędników, o których wiadomo, że w latach 1897-1917 pełnili funkcje cenzorskie w Warszawskim Urzędzie Pocztowym (Cenzory Rossijskoj imperii..., s. 462), w okresie 1897-1904 z pewnością pracowało siedmiu (choć z reguły nie przez cały czas), z tym, że ich podstawowym (jedynym?) zajęciem (podobnie jak niemal wszystkich pozostałych) była perlustracja korespondencji.

10 Ustaw o cenzure ..., s. 30. Zob. też art. 200 (s. 33). Zakres pojęcia „publikacje periodyczne” był ówcześnie węższy niż przyjmowany obecnie, gdyż według ustawy „Za wydawnictwa periodyczne uważa się: 1) gazety i czasopisma ukazujące się w postaci osobnych numerów, arkuszy i zeszytów; 2) zbiory lub antologie nowych, oryginalnych albo tłumaczonych, utworów lub artykułów różnych pisarzy, wydawane pod jednym ogólnym tytułem, częściej niż dwa razy w roku" (art. 114, s. 17). Do kategorii tej nie zaliczano więc na przykład kalendarzy, rocznych sprawozdań instytucji, a także roczników i półroczników naukowych.

11 W latach 1865-1871 oraz od listopada 1878 do końca 1904 roku wykazy te ukazywały się pod tytułem „Al’favitnyj Spisok Soinienijam Rassmotriennym Inostrannoju Cenzuroju w miesace 
(dalej: AGAD) w Warszawie Protokoły posiedzeń WKC z okresu objętego badaniami (12 roczników), zawierające uzasadnienia opinii cenzorskich ${ }^{12}$.

Przez długi okres podstawowym sposobem zaopatrywania się w periodyki zagraniczne była w Cesarstwie prenumerata pocztowa. W 1865 roku sprowadzono w ten sposób 480 tytułów, a w 1882 roku — 490. W 1888 roku spośród 578 pism, na które przyjmowano przedpłaty, cenzurowaniu podlegało 563. Było wśród nich zaledwie 38 periodyków w językach słowiańskich, w tym w języku polskim ${ }^{13}$. Wraz z ilościowym rozwojem prasy w Europie Zachodniej pojawiła się praktyka sprowadzania poszczególnych pism ,pod opaską". Z obawy przed zalewem tego typu przesyłek początkowo odsyłano je za granicę bez uprzedniej kontroli. Zaczęto je cenzurować dopiero w 1883 roku, ale nie dotyczyło to — z powodu braku personelu — dzienników. Jednak liczba tytułów importowanych drogą pocztową stale rosła — w 1895 roku było ich już 3397, a później nawet ponad $5000^{14}$. Pozostałe kanały (księgarnie, bagaż podróżnych, zorganizowany przemyt) odgrywały mniejszą rolę.

Wśród wszystkich sprowadzanych publikacji w języku polskim gazety i czasopisma stanowiły znikomą część. Ich udział (zarówno pojedynczych numerów, jak i ich ciągów) wynosił niespełna $1,5 \%{ }^{15}$. Poza tym, jak na początku XX wieku pisał Zygmunt Wasilewski,

[...] goda”, a od stycznia 1872 do października 1878 roku zamieszczano je w czasopiśmie „Ukazatel' po Delam Pečati”. Informacje uzupełniające, dotyczące pierwszej dekady badanego okresu, zawierają także dwa spisy zbiorcze: Alfavitnyj katalog knigam na pol'skom i žmudskom âzykah, zaprêsennym vpolne i pozvolennym s isklûčeniâmi, s 1830 po iûn' mesâc 1869 goda vklû́itel'no [Sankt-Peterburg 1869] i Dopolnitel'nyj k „Alfavitnomu katalogu 1869 goda” spisok knigam na pol'skom" âzyke, zapreŝennym i pozvolennym s isklûčeniâmi s Iûlâ $1869 \mathrm{~g}$. po Dekabr' $1876 \mathrm{~g}$. vklûcitel'no [Sankt-Peterburg 1877], a także dokumenty archiwalne przechowywane w Archiwum Głównym Akt Dawnych w Warszawie. Odnalezione opisy zweryfikowano z autopsji, a ich spis zawierają prace: J. Kostecki, M. Rowicka, Granice wolności stowa w zaborze rosyjskim w latach 1865-1904. Wykaz publikacji polskojęzycznych zakwestionowanych oraz dopuszczonych do obiegu przez carska cenzurę zagraniczna, T. 1-3, Warszawa 2006; J. Kostecki, Trudny proces przenikania..., s. 313-334.

12 Jest ich około 1,5 tysiąca, a pochodzą z lat 1867, 1873, 1879, 1885-1886, 1888-1891, 1897, 1899, 1903.

13 W.S. Izmozik, op. cit., s. 29. Od 1883 roku nie kontrolowano specjalistycznych czasopism naukowych, pism w językach mało rozpowszechnionych, a także adresowanych do redakcji periodyków rosyjskich (Ministerstvo vnutrennih del..., s. 119). W miesięcznych wykazach publikacji cenzurowanych publikacje polskojęzyczne i w „narzeczach słowiańskich” tworzyły jednak osobne kategorie.

14 Ministerstvo vnutrennih del..., s. 119. Zob. też Cenzory Rossijskoj imperii..., s. 54.

15 J. Kostecki, Trudny proces przenikania..., s. 188. Ze względu na to, że do cenzury trafiały druki o różnym statusie formalnym: książki jednotomowe (ale także ich zeszyty, poszyty), pojedyncze tomy wydawnictw wielotomowych, po kilka tomów wydawnictw wielotomowych, całe wydawnictwa wielotomowe, pojedyncze numery czasopism, ich zszywki, całe roczniki itp., to gdy 
Dzienniki zagraniczne po większej części, galicyjskie zaś i poznańskie w ogólności, mają zabroniony wstęp do Rosyi. Pism polskich zakordonowych nie przyjmuje zgoła poczta rosyjska, zaledwie kilka egzemplarzy każdego dziennika dostaje się w drodze specyalnego pozwolenia do redakcyi dzienników. I te egzemplarze poczta nadsyła redaktorom w zapieczętowanych kopertach, aby kogo po drodze nie zaraziły ${ }^{16}$.

\section{Podobnie relacjonował kilka lat wcześniej Georg M.C. Brandes:}

Za ostatniego pańskiego pobytu u nas, powiada młody poeta Mikołaj, wolno jeszcze było redakcyom otrzymywać wszystkie zagraniczne pisma. Teraz mamy spis gazet dozwolonych, spis niedługi. Bezwarunkowo nie wolno otrzymywać żadnego dziennika galicyjskiego, jeszcze zaś surowiej zabroniono przedrukowywać z nich cokolwiek. Gdyby przypadkiem w adresowanym do redakcyi rekomendowanym liście, który na poczcie otwierają, znaleziono wycinek z galicyjskiej gazety, zaraz czeka nas kara, choćby przesyłka miała miejsce bez naszej wiedzy. Karę wymierza się adresatowi, a nie nadawcy listu ${ }^{17}$.

Zdecydowana większość pism zakordonowych pozbawiona była zatem w zaborze rosyjskim (i oczywiście na terenie całego Cesarstwa) debitu komunikacyjnego, a więc zatrzymywano je już na granicy i w ogóle nie trafiały do cenzury. Przykładowo, w 1864 roku zakaz sprowadzania nie dotyczył — z pism galicyjskich — jedynie „Czasu”, „Dziennika Rolniczego”, „Przeglądu Lekarskiego”, „Gazety Lwowskiej” i „Ziemianina”, 18 a w 1871 roku drogą pocztową trafiały do Królestwa Polskiego zaledwie 83 egzemplarze siedmiu czasopism zakordonowych („Czas” — 50 egzemplarzy, „Dziennik Poznański” — 16, „Przegląd Lekarski” — 13, krakowski „Kraj” - 3 oraz „Gazeta Toruńska”, „Dziennik Polski” i „Gazeta Lwowska" - po 1) ${ }^{19}$. Biorąc pod uwagę przyrost oferty, nie lepiej było pod koniec wieku. W 1896 roku debit miało bowiem tylko 28 pism zakordonowych i spoza ziem polskich, wśród nich 16 miesięczników, 6 tygodników, 4 dwutygodniki i 2 kwartalniki, ale ani jeden dziennik. Ponad połowę stanowiły czasopisma lwowskie (15 tytułów); reszta pochodziła z: Poznania (6), Krakowa (5), Berlina (1) i Wiednia (1). Były to niemal wyłącznie periodyki wąskospecjalistyczne, głównie fachowe, adresowane do niewielkich grup odbiorców, w których prawdopodobieństwo pojawienia się niepożądanych treści było znikome: „Bartnik Postępowy”, „Czasopismo Techniczne”, „Czasopismo Towarzystwa Aptekarskiego”, „Echo z Afryki”, „Głuchoniemka”, „Gorzelnik”, „Kosmos”, „Kwartalnik Historyczny”,

miały ten sam rok wydania i sprowadzono je w tym samym roku, to w przywoływanych wykazach tworzono z nich jedną całość. Gdy zaś różniły się pod przynajmniej jednym z tych względów, to traktowano je jako odrębne jednostki. Szerzej na ten temat zob. J. Kostecki, M. Rowicka, op. cit., T. 1, s. 14.

${ }^{16}$ [Z. Wasilewski] Przygodny, Warszawa wspótczesna w dwunastu obrazach, Lwów 1903, s. 86 .

17 G.M.C. Brandes, Polska, przeł. Z. Poznański, Lwów 1898, s. 162.

18 „Dziennik Literacki” 1864, nr 5.

19 Z. Kmiecik, Prasa warszawska w okresie pozytywizmu (1864-1885), Warszawa 1971, s. 29. 
„Łowiec”, „Missye Katolickie”, „Muzyka Kościelna”, „Nowe Mody”, „Nowiny Lekarskie”, „Poradnik Gospodarski”, „Prawnik”, „Przegląd Hygieniczny”, „Przegląd Lekarski”, „Przegląd Literacki”, „Przegląd Sądowy i Administracyjny”, „Przegląd Weterynarski”, „Przewodnik Zdrowia”, „Rolnik dla gospodarzy wiejskich”, „Ster”, „Sylwan”, „Tygodnik Powieści”, „Wiadomości Lekarskie”, „Wiadomości Numizmatyczno-Archeologiczne” i „Ziemianin”20.

W całym badanym okresie w analizowanych spisach cenzuralnych znalazły się 93 tytuły importowanych pism polskojęzycznych, które rozpatrywano łącznie 193 razy $^{21}$. Jeden raz rozpatrywano 59 tytułów, dwa razy -15 , trzy razy -5 , cztery razy - 6, sześć razy — 3, osiem razy — 2, a dziewięć, dziesięć i jedenaście razy — po jednym tytule. Największą liczbę decyzji wydano w stosunku do „Kazań i Szkiców Księży Towarzystwa Jezusowego” (11), „Przewodnika Naukowego i Literackiego” (10), „Ludu” (9), „Biblioteki Kaznodziejskiej” i „Kroniki Emigracji Polskiej” (po 8) oraz „Dzwonka III Zakonu Ś.O.N. Franciszka Serafickiego”, „Przeglądu Polskiego" i „Strzechy” (po 6).

Czasopisma te pochodziły z co najmniej 17 ośrodków wydawniczych: Lwowa - 32, Krakowa - 25, Poznania - 11, Paryża - 6, Wiednia - 5, Cieszyna, Drezna, Mikołowa - po 2, Bendlikon, Bytomia GŚ, Chapelle-Montligeon, Chicago, Chyrowa, Gniezna, Milwaukee i Przemyśla — po 1. Jak widać, $3 / 5-2 / 3$ z nich ukazywało się w Galicji.

Blisko połowę z nich stanowiły miesięczniki (45 tytułów), resztę zaś: dwutygodniki (14), tygodniki (12), pisma ukazujące się nieregularnie (6), kwartalniki (5), dwumiesięczniki, dzienniki i czasopisma wydawane z inną niż wymienione częstotliwością (po 3$)^{22}$.

${ }^{20}$ Redakcye pism periodycznych krajowych oraz majacych debit u Cesarstwie. [...] Zagraniczne, „Kalendarz Rzymsko-Katolickiego Towarzystwa Dobroczynności przy Kościele św. Katarzyny", [R. 2:] na rok zwyczajny 1897, [Petersburg 1896], s. 223-224.

21 A mówiąc nieco bardziej precyzyjnie - w stosunku do których podjęto 193 decyzje, a zupełnie precyzyjnie — które stanowią 193 jednostki obliczeniowe (bo gdy w obrębie roku jedne numery danego czasopisma kwestionowano w całości, a inne dopuszczano do obiegu, to całość traktowano jako zakazaną częściowo, inaczej — dopuszczoną do obiegu warunkowo, po usunięciu pewnych fragmentów). Zob. też przypis 15. Liczba tytułów jest nieco mniejsza niż podana w książce J. Kostecki, Trudny proces przenikania..., gdyż w prezentowanej pracy zastosowano bardziej restrykcyjne kryteria zaliczenia danego tytułu do czasopism (wyeliminowano na przykład jednodniówki, a także części rocznych sprawozdań instytucji).

22 Częstotliwości ukazywania się dwóch pism nie zdołałem ustalić (być może były to efemerydy). 
Aż ponad 7/10 wszystkich tytułów stanowiły dwie kategorie pism: o treści ogólnej lub poświęcone tematyce z różnych dziedzin (42 tyt.) oraz religijne (24). Pozostałe dotyczyły: nauk społecznych (8); nauk stosowanych, sztuki lub sportu, historii (po 5); bibliografii, psychologii albo zajmowały się publikowaniem tekstów literackich (po 1$)^{23}$.

Choć czasopisma te w chwili rozpatrywania nie były pozbawione debitu komunikacyjnego, to odsetek negatywnych decyzji cenzorskich w stosunku do nich był znacznie wyższy niż w stosunku do wszystkich importowanych publikacji traktowanych łącznie. Aż 56\% przesyłek zakazano w całości, a 17,1\% dopuszczono do obiegu warunkowo. Aż blisko 3/4 (73,1\%) wszystkich spotkało się więc z ingerencją urzędów kontroli. W stosunku do całego importu odpowiednie wskaźniki wynosiły zaś: 30,8\%; 8,6\% i 39,4\%, czyli były blisko dwukrotnie niższe ${ }^{24}$.

2.1

Cenzura nie dopuściła do rozpowszechnia ani jednego numeru 48 (w tym 11 od razu pozbawiła debitu komunikacyjnego) spośród 93 czasopism, które próbowano sprowadzić do zaboru rosyjskiego. Dodatkowo los ten spotkał pięć innych tytułów, gdy rozpatrywano ich kolejne zeszyty. Łącznie zakaz dotknął 53 tytuły (57\% wszystkich), w tym bezterminowy 16 tytułów (ponad 17,2\%). Zatrzymywano pisma o rozmaitej tematyce, w tym adresowane do dość ograniczonego kręgu odbiorców. Wśród pozbawionych debitu przeważały periodyki lwowskie: „Posłaniec Serca Pana Jezusa do Narodu Polskiego” (1878) ${ }^{25}$, „Intencya Miesięczna czyli Posłaniec Apostolstwa Serca Jezusowego” (1883), „Muzeum” (1890), „Przewodnik Gimnastyczny »Sokół«” (1890), „Szkoła” $(1890)^{26}$, „Ekonomista Polski” $(1891)^{27}$, „Przewodnik dla Spraw Drukarsko-Litograficznych” (1891), „Tygodnik Ekonomiczny” (1891) ${ }^{28}$, „Gazeta Handlowo-Geograficzna” (1897), „Słowo Pol-

23 Tematyki dwóch czasopism nie udało mi się ustalić.

24 Zestawienie pokazuje tylko skalę zróżnicowania, natomiast jeśli chodzi o konkretne wielkości, ma wyłącznie wartość poglądową, gdyż w odniesieniu do lat 1865-1871 nie dysponowałem pełnymi danymi dotyczącymi decyzji pozytywnych. Precyzyjne obliczenia można przeprowadzić tylko dla okresu 1872-1904. Ich wyniki znajdują się w J. Kostecki, Trudny proces przenikania...

${ }^{25} \mathrm{~W}$ nawiasie zamieszczam rok decyzji. Dla zachowania konsekwencji w całej pracy podaje daty według tak zwanego starego stylu (kalendarza juliańskiego).

26 Wcześniej, w latach 1868 i 1869, warunkowo zezwolono na rozpowszechnianie większości numerów rocznika 2, w pierwszym wypadku kwestionując s. 53-64 drugiej paginacji, a w drugim s. 9-24 trzeciej paginacji. W obu wypadkach był to bezpłatny dodatek do pisma „Nowiny Księgarskie" księgarni Karola Wilda we Lwowie. Zasada usuwania z publikacji wszelkich wykazów druków nieznanych cenzurze lub przez nią kwestionowanych obowiązywała do 1897 roku.

27 Najpierw nie dopuszczono do obiegu numerów 11-12 tomu 4, a rozpatrując prawdopodobnie numery tomów 5-6, zakazano rozpowszechnia całego tytułu.

28 Był to dodatek do „Ekonomisty Polskiego”, także pozbawionego debitu komunikacyjnego. 
skie” (1897). Pojedyncze tytuły ukazywały się w Krakowie — „Przewodnik Bibliograficzny”(1890) ${ }^{29}$ i „Miesięcznik Religijny” (1903) ${ }^{30}$, Poznaniu — „Przegląd Kościelny” (1890) ${ }^{31}$, Paryżu — „Pobudka” (1892), Milwaukee — „Kuryer Polski” (1893), Cieszynie — „Niewiasta” (1896). Jak widać, większość decyzji podjęto w latach 90 .

W zależności od charakteru pisma uzasadnienia cenzorskie miały różny charakter. Przykładowo, cenzor Awgustin Awgustinowicz Łagodowski, zaliczając „Przegląd Kościelny” do czasopism, „które ze względu na swe szkodliwe nastawienie podlegają całkowitemu zakazowi bez uprzedniego cenzuralnego rozpatrywania", argumentowat:

„Przegląd Kościelny”. Pismo miesięczne poświęcone nauce katolickiej i życiu kościelnemu [...]. Poświęcone problemom dogmatycznym, egzegetyce, patrystyce i propagandzie katolickiej na całej kuli ziemskiej. Na końcu pisma zwykle znajduje się kronika, której autor niezwykle żywo przedstawia cierpienia Kościoła katolickiego w Rosji — tym państwie ordynarnej przemocy i barbarzyńskiej samowoli. Na przykład artykuł zamieszczony niedawno z powodu śmierci metropolity mohylewskiego [Aleksandra Kazimierza] Gintowta [-Dziewałtowskiego] lub notatka, o której

29 Wcześniej, w 1879 roku, dopuszczono do obiegu numer 2 rocznika 2.

30 Do czasopisma tego nie udało mi się dotrzeć. Według cenzora Władimira Stiepanowicza Dragomireckiego (AGAD, WKC, sygn. 44: Protokoły posiedzeń — dalej: PP 1903, nr 26 z 9 lipca, k. 298 v.), ,Wskazana broszura religijna jest identyczna z wydawnictwem jezuitów krakowskich, zakazanym przez Ministra Spraw Wewnętrznych (patrz cyrkularz Zarządu Głównego do spraw Druku z 3 września 1883 r. No 3231). Jezuici krakowscy pragnąc, oczywiście, rozpowszechnić swoją propagandę w tutejszym kraju, wydrukowali swoje wydawnictwo »Intencya Miesięczna» pod innym tytułem (»Miesięcznik Religijny«), zamieszczając na jej okładce adres warszawskiej firmy księgarskiej M. Szczepkowskiego (Nowogrodzka 23)”. „Intencya Miesięczna...” wcześniej ukazywała się we Lwowie.

31 Decyzję tę podjęto przy trzecim zetknięciu się z pismem: w 1888 roku dopuszczono do obiegu dwa numery z tegoż roku, a w jednym nakazano usunąć 21 wersów, natomiast w 1889 roku zatrzymano jeden numer $\mathrm{z}$ roku poprzedniego. Wspomniany fragment pochodził z działu pod tytułem „Kronika” i dotyczył problemu unitów: „Dalsze kroki rządu moskiewskiego w celu zagłady unii [...]. Rząd rosyjski ustanowił na ziemiach nieszczęśliwych Unitów, tj. guberniach lubelskiej, siedleckiej i suwalskiej, komisye złożone z naczelnika każdego obwodu, popa prawosławnego i dziekana katolickiego, które mają decydować, kto należy do kościoła katolickiego a kto do cerkwii prawosławnej. Schizmatycki pop każdej miejscowości przedkłada tej komisyi wykaz osób i rodzin, które podług jego zdania do schizmy należeć powinny, katolicki zaś pleban tejże miejscowości wypowiada swoje zdanie. Komisya bada, głosuje i rezultat przesyła schizmatyckiemu konsystorzowi w Chełmie, który rozstrzyga jako najwyższa instancya. Na listę wpisuje schizmatycki duchowny wedle ukazu wszystkich Unitów, oraz tych wszystkich, którzy z jakiejkolwiek przyczyny ochrzczeni zostali w unickiej cerkwi, a takich łacinników nie mało w Chełmszczyźnie. Do tej kategorii zaliczają nawet tych, których dziad lub pradziad ochrzczony był lub brał ślub w cerkwi. Wystarcza już odległe powinowactwo z prawosławnym, aby do tego spisu dostała się cała rodzina. Jest to zamach nie tylko na Kościół unicki, ale i na Kościół łaciński, któremu wydrze schizma mnóstwo katolików. Położenie katolickich księży jest wobec tego bardzo trudne. Protest swój musi udowodnić metrykami, że ani zapisana osoba, ani rodzice, ani dziadowie po mieczu i kądzieli nie byli unitami” (s. 557 w. 1-17 d., s. 558 w. 1-4 g.). 
P. Cenzor meldował Komitetowi na dzisiejszym posiedzeniu z powodu zakazania w granicach imperium Towarzystwa Serca Jezusowego, w pełni charakteryzują ogólne nastawienie tego organu $[\ldots]^{32}$.

Natomiast Dragomirecki w cytowanym już bardzo obszernym wniosku dotyczącym „Miesięcznika Religijnego” skupił się na demaskowaniu szkodliwych intencji redakcji, wzywającej wiernych do podejmowania działalności misyjnej. Stwierdzał on między innymi:

Autor broszury pragnąc zachęcić członków do jezuickiego towarzystwa „Apostolstwa Serca Jezusa" napomina katolików, by połączyli się i wzięli na siebie rolę apostołów. [...] Działalność apostolska, mówi autor (str. 6), niezbędna jest w chwilach ciężkich i niebezpiecznych dla Kościoła i wiary, w chwilach prześladowań, które kieruje się głównie przeciwko duchowieństwu, ponieważ wrogowie Kościoła dobrze zdają sobie sprawę z jego znaczenia [...]. Na potwierdzenie swoich słów autor wskazuje na politykę rządu francuskiego, lecz można przypuszczać — kontynuuje on —że prześladowanie rozpoczęte we Francji ogarnie wszystkie kraje katolickie. Opierając się na takich przypuszczeniach autor wzywa wszystkich wiernych świeckich, by uzbroili się dla obrony wiary i Kościoła. Powinni oni mężnie i z zapałem zastąpić duchowieństwo w misji apostolskiej (str. 7). Z tym wezwaniem autor zwraca się do całego świata katolickiego w celu organizowania kół mężów apostolskiego ducha i serca (str. 7). [...]

W zakończeniu broszury (str. 30-31) zamieszczony jest kalendarz na miesiąc styczeń z objaśnieniami i umówionymi oznaczeniami, z których można dowiedzieć się o osiągnięciach propagandy jezuickiej. Tak na 1 stycznia umieszczona jest modlitwa do Najświętszego Serca Pana Jezusa o spełnieniu rozmaitych próśb 1310 osób, 166 rodzin, 55 parafii, na 2 - jezuici proponują modlić się za 1867 osób, które zwróciły się do nich z jakimiś prośbami, szczególnie polecają oni 72 prośby. [...] Takież modlitwy umieszczono na wszystkie inne dni miesiąca. [...] Oprócz wyżej wskazanych artykułów w broszurze znajduje się obrazek Zbawiciela z wizerunkiem serca (str. 13), który zakazał Warszawski Generał Gubernator 2 kwietnia 1891 r. No 569.

Biorąc pod uwagę powyższe, a głównie — zgodnie z art. 182 Ustawy o cenzurze i dru$\mathrm{ku}$ - cel i zamiar autora, by przygotować grunt i umocnić w tutejszym kraju propagandę jezuitów krakowskich, proponowałbym broszurę „Miesięcznik Religijny” zakazać na podstawie rozporządzenia Zarządu Głównego do spraw Druku z 3 maja 1874 r. [1871?] No 233 (o wydawnictwach jezuitów) $[\ldots]^{33}$.

Oczywiście na inne elementy zwracał uwagę Nikołaj Pawłowicz Kuzniecow, wnosząc o pozbawienie debitu branżowego „Przewodnika dla Spraw Drukarsko-Litograficznych":

W opinii cenzora to niewielkiej objętości wydawnictwo przeznaczone jest prawdopodobnie do rozpowszechniania wśród drukarzy, zwłaszcza wśród zecerów, na ile można to wywnioskować ze znacznej liczby przejętych egzemplarzy tego wydawnictwa, adresowanych na nazwiska właścicieli drukarni w Kraju Przywiślańskim.

Treścią wydawnictwa systematycznie stają się zagadnienia wolności druku, poprawy bytu zecerów i uczniów (skrócenie dnia pracy, podniesienie płac), organizacji samopomocy wśród nich itp. robotnicze problemy. Ponadto wydawnictwo to nosi odcień polskopatriotyczny. [...]

32 AGAD, WKC, sygn. 40: PP 1890, nr 2 z 15 stycznia, k. 10-11.

33 AGAD, WKC, sygn. 44: PP 1903, nr 26 z 9 lipca, k. 299-301 v. 
Zgadzając się z wnioskiem referenta, Komitet, na podstawie prawa, udzielonego zarządzeniem Rady Zarządu Głównego do spraw Druku z 27 maja 1872 r, No 2236, orzekł: poddać przedstawione zagraniczne wydawnictwo periodyczne całkowitemu zakazowi, bez dalszego cenzuralnego rozpatrywania i o takiej decyzji, zgodnie z zarządzeniem z 6 czerwca 1879 roku No 2077 zameldować Zarządowi Głównemu do spraw Druku ${ }^{34}$.

Jeszcze inaczej argumentował swe wnioski Władimir Michajłowicz Iwanowski. W wypadku „Muzeum” zwracał on uwagę, że należy ono „do grona organów wojującego polonizmu i jako takie odznacza się systematyczną wrogością do Rosji”35, a w odniesieniu do „Przewodnika Gimnastycznego »Sokół«” i „Szkoły” na poparcie takiej opinii podał również przykład ją uzasadniający. Jego zdaniem oba periodyki

należą do grona tych zagranicznych wydawnictw polskich, dla których nieprzejednana wrogość do Rosji stanowi, można powiedzieć, podstawowy dogmat ich katechizmu politycznego. Finalnym celem agitacji patriotycznej podobnych wydawnictw jest sławetne „odrodzenie Polski”. Tak np. w No 7 „Przewodnika gimnastycznego”, z okazji przeniesienia prochów Mickiewicza do Krakowa, Polacy wzywają, by nad grobem Mickiewicza złożyć uroczyste przyrzeczenie poświęcenia wszystkich swoich sił sprawie odrodzenia Polski ${ }^{36}$.

Komitet zaakceptował obie propozycje cenzora, powołując się na te same zarządzenia co przy zatwierdzaniu propozycji Kuzniecowa.

2.2

W wielu wypadkach do zaprzestania sprowadzania danego czasopisma niepotrzebne było nawet pozbawienie go debitu komunikacyjnego, wystarczał pierwszy zakaz rozpowszechnia jakiegoś numeru lub rocznika ${ }^{37}$. Tak było w wypadku aż 32 periodyków z 14 ośrodków, w tym 6 zagranicznych, 4 galicyjskich oraz 4 z dzielnic pruskich. Tym razem najczęściej były to pisma krakowskie (8 tytułów) i lwowskie $(5)^{38}$.

34 AGAD, WKC, sygn. 41: PP 1891, nr 28 z 23 lipca, k. 190 v.-191.

35 AGAD, WKC, sygn. 40: PP 1890, nr 23 z 18 czerwca, k. 140.

36 AGAD, WKC, sygn. 40: PP 1890, nr 33 z 27 sierpnia, k. 194-194 v.

37 Zachowane materiały nic nie mówią ani o liczbie importowanych egzemplarzy, ani o sposobie ich sprowadzania. Nie wiadomo więc, do ilu osób one trafiały (stąd na przykład sformułowania o ,wprowadzaniu pism do obiegu” lub „na rynek” czasem należy traktować ostrożnie). Z pewnością przynajmniej niektórzy wydawcy zagraniczni podejmowali próby zainteresowania swą ofertą czytelników w zaborze rosyjskim, ale to przyszli odbiorcy podejmowali decyzję o prenumeracie czy zakupie jakiegoś pisma. Trudno jednak powiedzieć, jak wyglądał mechanizm rezygnacji z przedpłaty w wypadku ingerencji cenzorskich, jaka była dynamika tego procesu. Problem ten jest istotny zwłaszcza w tych wypadkach, gdy werdykty urzędników w stosunku do kolejnych numerów pism różniły się.

38 Pozostałe pisma wychodziły w: Poznaniu (4), Paryżu (4), Mikołowie (2) oraz w Bendlikon, Bytomiu, Chapelle-Montligeon, Chicago, Chyrowie, Dreźnie, Gnieźnie, Przemyślu i Wiedniu (po 1). 
W zbiorze tym wyróżniały się ilościowo (12 tytułów) czasopisma religijne: „Wiara” (1866), „Kaznodzieja Katolicki” (1871), „Promotor Nabożeństwa do św. Józefa i Przenajświętszej Rodziny” (1874), „Orędownik Arcybractwa N. Niep. Serca Maryi ku Nawracaniu Grzeszników” $(1884)^{39}$, „Zdrowaś Marya” (1886), „Dobry Pasterz” (1888), „Chleb św. Antoniego” (1895), „Głos św. Antoniego z Padwy” (1896), „Posłaniec Matki Boskiej Nieustającej Pomocy” (1900), „Biuletyn Dzieła Miłosierdzia Chrześcijańskiego” (1901), „Z Chyrowa” (1902) i „Kazalnica” (1903).

Argumenty za niedopuszczeniem do obiegu poszczególnych numerów nie różniły się niczym od tych używanych w wypadku wniosków o pozbawienie danego tytułu debitu komunikacyjnego. I w tym wypadku zdarzały się zarówno uzasadnienia lakoniczne, uzupełniane co najwyżej odwołaniami do odpowiednich zarządzeń Zarządu Głównego do Spraw Druku (dalej: ZGdsD), jak na przykład w wypadku opinii Dragomireckiego o „Kazalnicy” (R. 1, z. 1):

Na str. 24 zamieszczony jest artykuł o wierze katolickiej, którą autor uważa za ,jedynie prawdziwą", pozostałe wyznania chrześcijańskie nazywa on zbłądzeniem.

Komitet, wysłuchawszy raportu p. Starszego Cenzora Dragomireckiego i zgadzając się z jego opinią, postanowił: broszury te zakazać do obiegu wśród publiczności na podstawie rozporządzenia Zarządu Głównego do spraw Druku z 10 kwietnia 1869 r. i 20 kwietnia 1872 r. No $163^{40}$,

jak i rozbudowane, na przykład jak w wypadku uzasadnienia Nikołaja Glebowicza Wołoczeninowa dotyczącego niedopuszczenia do obiegu „Promotora Nabożeństwa do św. Józefa i Przenajświętszej Rodziny” (R. 4, z. 2-3):

W pierwszej z tych broszur, na str. 108-110 komunikuje się wiadomość, że w 1872 roku w Pogorzelicy, blisko granicy Królestwa Polskiego założono bractwo św. Józefa, mające taki statut jak bractwo tego świętego w Poznaniu. Informuje się przy tym, ze nowe bractwo ma wszystkie prawa i przywileje, nadane przez papieży [arcy]bractwu poznańskiemu, a także, że mimo stałych starań duchowieństwa, bractwo to wskutek przeszkód ze strony władz świeckich, z wielkim trudem rozprzestrzenia się na pogranicznych terenach z ludnością polską, i dlatego radzi: [„Módlmy się tymczasem o braci naszych w tamtych stronach, aby mimo trudności i przeszkód, z jakiemi mają do walczenia, wytrwali w nabożeństwie swem do św. Józefa, i żeby P. JEZUS raczył im użyczyć tej pociechy, jakiej nam nie poskąpił” — s. 110] ${ }^{41}$. W drugiej broszurze na str. 155, w artykule [„Ś. Józef Protektor zakładów duchownych"] — autor ubolewa, że współczesny materializm zmniejsza corocznie liczbę osób pragnących poświecić się stanowi duchownemu, co musi mieć straszne skutki dla społeczeństwa i Kościoła. Na ostatniej stronie [s. 170] autor komunikuje, że za wstawiennictwem kardynała Pawła Cullana [arcybiskupa dublińskiego] papież, 28 października 1872 r., ustanowił nowy szkaplerz [N.] Serca [Jezusowego] (na białym tle — czerwone serce z napisem [Stój, Serce JEZUSA ze mna]); każdemu, noszącemu ten znak, papież wyznaczył sto dni odpustu.

Przedstawiając te broszury do rozpatrzenia przez Komitet, P. Wołoczeninow zaproponował nie dopuścić ich do obrotu wśród publiczności, mając przy tym na względzie tę okoliczność, że

39 Jednocześnie rozpatrzono wówczas numery z trzech roczników.

40 AGAD, WKC, sygn. 44: PP 1903, nr 24 z 24 czerwca, k. 271-271 v.

$41 \mathrm{~W}$ nawiasach kwadratowych zamiast własnych tłumaczeń fragmentów tekstu przełożonych przez cenzora zamieszczam tekst oryginalny. 
bractwa istniejące w tutejszym kraju działają prawdopodobnie tajnie, i dlatego informowanie o nowych bractwach powinno być uznane za niewłaściwe.

Komitet zgodził się z opinią P. Cenzora ${ }^{42}$.

Pozostałe czasopisma z tej grupy (20) miały na ogół charakter ogólny, składały się z materiałów o różnej tematyce; tylko pojedyncze adresowano do określonych grup odbiorców (dzieci, studentów, kobiet, tak zwanego ludu, osób o sprecyzowanych zainteresowaniach, na przykład muzycznych). Były to: „Pismo Zbiorowe” (1865), „Postęp” (1865), „Ognisko” (wydawane przez Walerego Wielogłowskiego, 1866), „Tygodnik Wielkopolski, Naukowy, Artystyczny i Literacki” (1871), „Gazeta Polska w Chicago” (1874), „Dziennik Mód” (1875), „Tydzień Polityczny, Naukowy, Artystyczny i Literacki” (przed 1876), „Towarzysz Pilnych Dzieci” (1876), „Monika” (1877), „Zbratnienie” (1881), „Przegląd Rzeczy Polskich” (1882) ${ }^{43}$, „Lutnia Polska” (1885), ,Śmieszek” (1886), „Głos Polski” (1887), „Ruch” (1887), „Światło” (1887), „Ognisko” (pod redakcją Kazimierza Przerwy Tetmajera, 1889), „Przegląd Akademicki” (1890), „Iris” (1899) i „Krytyka” (1903).

Podobnie jak uzasadnienia cytowane wcześniej, tak i używane w tym wypadku miały różną objętość, z tym że rozpatrywanym pismom zarzucano głównie nastawienie antyrosyjskie. W opinii o lwowskim miesięczniku „Iris. Piśmie literackim i artystycznym” (R. 1, z. 6-7) czytamy na przykład: „Na skutek skrajnie polsko-patriotycznej tendencji i nienawistnego stosunku do rosyjskiego rządu P. [Władimir Uljanowicz] Trofimowicz zaproponował zeszyty te zatrzymać"44. Natomiast decyzję o niedopuszczeniu do obiegu jednego z numerów krakowskiego „Śmieszka. Dwutygodnika Krytyczno-Humorystycznego” z 1886 roku Łagodowski uzasadniał następująco:

Zamieszczony w No 13 czasopisma „Śmieszek”, na str. 2 i 3, „Krakowiak” stanowi [...] bezczelny paszkwil przeciwko osobistości Suwerennego Cesarza, naszego rządu i narodu rosyjskiego, który jasno świadczy, że redakcja „Śmieszka” nie zasługuje na żadne zaufanie.

Komitet postanowił: przedstawić to do uznania Zarządu Głównego do spraw Druku, ze swym wnioskiem, że wskazane czasopismo nie tylko nie może być dopuszczone do sprzedaży detalicznej w granicach Imperium, lecz także import jego powinien być zakazany ${ }^{45}$.

Nie mam żadnych wątpliwości co do tego, że wniosek o pozbawienie „Śmieszka" debitu komunikacyjnego został przez ZGdsD uwzględniony. Znacznie obszerniejszą opinię sporządził Iwanowski:

[...] w szóstym zeszycie czasopisma „Krytyka”, za miesiąc czerwiec 1902 r. zwracają na siebie uwagę artykuły: [Ludwik Kulczycki:] „Finlandya a Rossya”, [Jan Sten, właśc. Ludwik Bruner:

42 AGAD, WKC, sygn. 34: PP 1873, nr 49 z 11 grudnia, k. 207-208.

43 Rozpatrzono aż cztery tomy tego nieregularnego periodyku z różnych lat, ale zrobiono to jednocześnie.

44 AGAD, WKC, sygn. 43: PP 1899, nr 31 z 10 sierpnia, k. 305-305 v.

45 AGAD, WKC, sygn. 37: PP 1886, nr 32 z 7 sierpnia, k. 134. 
Młoda Polska. (Serya druga)] „Włodzimierz Tetmajer”, „Kronika Warszawska” [Lambro, właśc. Andrzej Niemojewski: „Kronika miesięczna”] i [Stefan Odrzywolski:] „Z powodu ostatnich występów dra Lutosławskiego".

W pierwszym z nich mówi się właściwie o prześladowaniach przez rząd rosyjski Finlandii. Przedstawiwszy w odpowiednim oświetleniu wszystkie znane fakty, autor artykułu dochodzi do wniosku, że sytuacja Finlandii byłaby bez wyjścia, gdyby nie nadzieja na wzmocnienie ruchu rewolucyjnego w Rosji, który powinien położyć kres absolutyzmowi i jednocześnie zapalić zorzę wolności dla wszystkich narodowości uciskanych przez Rosję.

W artykule „Włodzimierz Tetmajer” rozwija się myśl, że odrodzić Polskę może tylko polski chłop, co zrozumiał i wyraził w swojej artystycznej działalności polski artysta-malarz i pisarz Wł. Tetmajer.

W artykule „Kronika Warszawska” między innymi opisuje się śmierć poległego z rąk zabójcy ministra [Dmitrija Siergiejewicza] Sipiagina; ten ostatni przedstawiony jest jako bezbożnik, który wypędził [popa], gdy przyszedł on [z pociechą religijną], i który wcale nie jest wiernym sługą swojego monarchy ${ }^{46}$.

Na koniec, w artykule „Z powodu ostatnich występów dra Lutosławskiego” otwarcie wyraża się myśl, że tylko drogą krwawej rewolucji a nie drogą mistycznych majaczeń w guście Lutosławskiego można uratować Polskę ze szponów Rosji.

Dziesiąty zeszyt czasopisma „Krytyka” cały poświęcony jest Marii Konopnickiej z okazji jej jubileuszu ${ }^{47}$; na pierwszy plan wysuwa się oczywiście te jej utwory, w których polska poetka okazuje się wyrazicielką cierpień ludu polskiego i zwiastunką rewolucji społecznej, jako naturalnego następstwa istniejących nienormalnych stosunków między klasami społecznymi, a także i te, w których Konopnicka występuje, jako gorąca patriotka, gdyż ona „contra spem — spero”.

$\mathrm{Z}$ uwagi na taką treść rozpatrywanych dwóch zeszytów czasopisma, proponowałbym nie dopuszczać ich do obiegu wśród publiczności.

Komitet, wysłuchawszy raportu p. Starszego Cenzora Iwanowskiego i zgadzając się z jego opinią postanowił: zeszytów VI i X czasopisma „Krytyka” z 1902 r. nie dopuścić do obiegu wśród publiczności, o czym zawiadomić p. Osobnego Moskiewskiego Cenzora Cenzury Zagranicznej ${ }^{48}$.

Nie sposób dociec, dlaczego używając podobnych, a nawet bardziej stanowczych argumentów niż cytowane na początku, nie starano się o pozbawienie debitu komunikacyjnego dwóch ostatnich grup czasopism. Tym trudniej zrozumieć sytuacje, gdy decyzje o zakazie rozpowszechniania podejmowano w stosunku do kilku kolejnych przesyłek z różnymi numerami (rocznikami, zeszytami) danego periodyku. Paryską „Kronikę Emigracji Polskiej” zatrzymywano w 1882 roku osiem razy, lwowską „Strzechę” w latach 1868-1872 — sześć razy, krakowski „Dzwonek III Zakonu Ś.O.N. Franciszka Serafickiego” w latach 1889-1896 — także sześć razy, a drezdeński „Przegląd Powszechny” (lata 60.), krakowskie „Echo

46 W tekście artykułu zamieszczono sformułowanie „Naplewat’ mnie uż na caria — burknął wierny sługa".

47 Znalazły się tam następujące teksty: f., Hołd poetce, s. 209-214; K. Radosławski, Idee społeczne w utworach Konopnickiej, s. 214-228; L. Belmont, Marya Konopnicka jako nowelistka, s. 228-241; W.M. Kozłowski, Motywa filozoficzne w poezyach M. Konopnickiej, s. 242-254; Z literatury o Konopnickiej, s. 254-257; J. Lorentowicz, Liryka Maryi Konopnickiej, s. 257-264; K. Krauz, Kwestya kobieca w poezyach Konopnickiej, s. 264-269; Sprawozdania, s. 269.

48 AGAD, WKC, sygn. 44: PP 1903, nr 1 z 7 stycznia, k. 2-3 v. 
Trzeciego Zakonu św. o. Franciszka” w latach 1884-1885, wiedeńską „Illustrowaną Bibliotekę Rozmaitości” w latach 1891-1892 — po dwa razy. Przynajmniej w tym ostatnim wypadku pewną rolę mogła odegrać ogólnikowa formuła użyta w pierwszym uzasadnieniu odmowy dopuszczenia pisma do obiegu: „Z uwagi na tendencyjność tego wydawnictwa, P. [Iwan Jefimowicz] Bielinski zaproponował poddać je zakazowi’49.

2.3

Sprowadzanie kolejnych numerów danego czasopisma, choć poprzednie przesyłki z nim były w całości (w części) zatrzymywane przez cenzurę, okazywało się czasem skuteczne i udawało się jednak wprowadzić na rynek zaboru rosyjskiego niektóre jego numery, bądź w ogóle bez ingerencji, bądź tylko warunkowo. Dlaczego jednak zdarzało się, że rezygnowano z dalszego importu nie tylko po pierwszym całkowitym zakazie przesyłki z jakimś pismem, ale także po pierwszej ingerencji dotyczącej jakiegoś fragmentu tekstu? Tak było w wypadku „Rolnika” (1868), „Sobótki” (1869), „Na dziś!” (1872), „Tygodnia Polskiego” (1881) i „Szczutka” (1883). Natomiast po drugiej ingerencji w treść pisma zrezygnowano z importu „Zwiastuna Ewangelicznego” (1867-1868) i „Przemysłu Artystycznego" (1896-1897). Być może decydujący był okres, w jakim wydawano te decyzje, ich większość (z wyjątkiem odnoszącej się do „Przemysłu Artystycznego”) przypadła bowiem na pierwszą połowę badanego okresu. Zresztą ingerencje w oba sprowadzone numery wymienionego dwumiesięcznika były niewielkie. W pierwszym usunięto jedynie tablicę 4 przedstawiającą drzwi z kutego żelaza wykonane w 1894 roku w warsztacie Józefa Goreckiego według projektu Karola Knausa, a umieszczone w portalu kościoła na Skałce. Jak się wydaje przyczyną były stanowiące ich element dwie tarcze herbowe, jedna z wizerunkiem Orła, druga Pogoni, gdyż cenzura konsekwentnie eliminowała wszelkie odniesienia do Polski w granicach przedrozbiorowych. W drugim numerze Kuzniecow zaproponował usunąć s. 49, gdyż znalazło się na niej między innymi krótkie „Sprawozdanie zarządu Muzeum narodowego w Rapperswylu" ${ }^{50}$. Wspomina się w nim między innymi o pozyskaniu do Muzeum w 1895 roku serca Kościuszki („,Droga ta Polakom pamiątka umieszczona będzie w mauzoleum, wybudowanem na dziedzińcu Muzeum [...]"), o tym, że placówkę odwiedziło w tymże roku przeszło 400 osób z Polski, i że w depozycie Muzeum znajdują się „fundusze Skarbu Narodowego”.

Także spośród czterech rozpatrywanych numerów „Sobótki” nakazano usunąć niespełna półtorej strony (s. 26-27) numeru 4, gdzie zamieszczono kolejny odcinek powieści Stefana Chorma Zmartwychwstanie z trumny. Obrazek z nieda-

49 AGAD, WKC, sygn. 41: PP 1891, nr 16 z 29 kwietnia, k. 109 v.

50 AGAD, WKC, sygn. 42: PP 1897, nr 11 z 18 marca, k. 72 v. 
lekiej przeszłości, której akcja rozgrywa się w okresie powstania styczniowego. Znalazły się tam takie na przykład passusy, jak dialog kosyniera i strzelca:

„Albo też Moskale, skryci w sośninie, wysłali szpiega, by nas odszukał”, szepnął lękliwie kosynier. „To go schwycimy, zaprowadzim do obozu i powiesim na suchej gałęzi” (s. 26)

czy rozmowa owego kosyniera z gajowym:

„A skądżeście wy?” — ciekawie zagadnął gajowy. — „Z pod Tarnowa!” — „Z tak daleka się bić tu przybyliście?” — „A bo to nie jeden kraj? bośmy to nie bracia, i nie jednej wiary? — rzekł kosynier. - Powinniśmy się bronić! - Nie możemy pozwolić, by Moskal krzyże święte rąbał, modlić się zabraniał, plugawił kościoły, bezcześcił obrazy naszej królowej Częstochowskiej i profanował nasze najświętsze sakramenta" (s. 27).

Niewiele zakwestionowano też w „Zwiastunie Ewangelicznym”. Spośród siedmiu numerów z roku 1867 w dwóch nakazano wykreślić łącznie niespełna sześć stron — w numerze 5 wystąpienie Jana Śliwki na konferencji nauczycieli śląskich w Cieszynie poświęcone konieczności nauczania w szkołach języka polskiego, zawierające przy tym wiele wskazówek metodycznych (od s. 114, w. 21 d. do s. 117, w. 11 g.), a w numerze 7 tekst Wiadomości z Kościoła i o Kościele (od s. 167, w. 12 g. do s. 168, w. 12 g.) o, jak stwierdził Julij Osipowicz Szriejer,

języku polskim w początkowych szkołach ewangelickich, na tej podstawie, że w nim przytacza się myśl o wspieraniu polskiej narodowości w szkołach ewangelickich, a ponieważ wskazane pismo wydaje się właściwie dla mieszkańców Królestwa Polskiego, to przytoczony pogląd oczywiście odnosi się i do początkowych szkół ewangelickich w Królestwie Polskim ${ }^{51}$.

Natomiast jeśli chodzi o dwa numery z roku 1868 , to tylko w jednym z nich zakwestionowano 30 wersów. Był to końcowy fragment działu „Przegląd Literacki” dotyczący Piosnek dla dziatek wspomnianego Śliwki, gdzie zastrzeżenia wzbudziły zapewne passusy w rodzaju: „Tylko poezja biblijna i snuta na tle dziejów ojczystych, może z ludu wyrobić naród, z dzieci, dzielnych mężów, z dziewczątek, szlachetne matrony" (s. 42).

W pozostałych czasopismach ingerencji było więcej. Spośród 11 numerów tomu 1 (1867) lwowskiego „Rolnika” okaleczono sześć, usuwając łącznie siedem stron $^{52}$. W wypadku numeru 2 (s. 30) w rozprawie Antoniego Gostkowskiego $O$ bankach $i$ wplywie ich na pomyślność rolników chodziło prawdopodobnie o sformułowanie „hr. Andrzeja Zamojskiego, ten ideał magnata i kupca polskie-

51 AGAD, WKC, sygn. 33: PP 1867, nr 27 z 6 lipca, k. 291-291 v.; zob. też nr 19 z 11 maja, k. 195 v.-196. W rzeczywistości tekst ten dotyczył postulatu, by protokoły wizytacyjne w polskich szkołach ludowych sporządzać nie w języku niemieckim, lecz polskim. Interpretacja cenzora miała więc - ostrożnie mówiąc — charakter rozszerzający.

52 Tak naprawdę zastrzeżenia dotyczyły tylko ich fragmentów, ale na początku badanego okresu w wykazach cenzuralnych nie podawano numerów kwestionowanych wersów, a tylko numery całych stron. 
go” (w. 1-2 g.), a w numerze 6 (s. 141) o następujący fragment działu „Przegląd handlowy":

Smutny stan potężnie zadłużonych majątków niemieckich świadczy najwymowniej zarazem, że różnica pomiędzy gospodarstwem Polaków prześladowanych obczyzną i nieszczęściami narodu swego, trzymającymi się jednak dobrze, a pomiędzy gospodarstwem Niemców, którym sprzyjają wszystkie okoliczności kredytu, zachęceń rządowych, kształcenia się w ich zakładach narodowo-niemieckich, nareszcie ściślejsza ich solidarność i t.p. —że ta różnica w wyniku ostatecznym przeważa na stronę inteligencji polskiej. Tak być zresztą powinno, gdyż odwieczny kościół boży jest naród polski, a nie żaden inny, i od niego jedni chleb brali, a bliżsi pouczali się jak rolę uprawiać.

Przy swobodzie łatwo by zawsze dowieść można, że jajko od kury mądrzejszym być nigdy nie może (w. $17-28$ g.).

W numerze 8 (s. 185) wątpliwości wzbudził zapewne fragment działu „Przegląd rolniczo-kupiecki” dotyczący braku zboża na rynku europejskim i spodziewanego kryzysu handlowego

Dowozy zaś, z zniszczonych a najżyźniejszych krain Polski przez dzicz mongolską maleją z dniem każdym. Okrucieństwo ludzi wpycha nas w grób przedwczesny, a sprawiedliwa ręka Boga już się ukazuje tym, co na wymordowanie nas obojętnie patrzą, bo straszliwe widmo głodu straszy świat. [...]

Jako dowód upadku wszelkiego handlu w nieszczęśliwej Polsce może posłużyć także sprawozdanie ostatnie zarządu kolei warszawsko-bydgoskiej; otóż ta tak naturalna linja komunikacyjna wydała 80.198 r.sr. deficytu (w. 19-23 g., 1-4 d.),

w numerze 10 fragment tego samego działu (s. 232) poświęcony obawom przed klęską głodu w czasie nadchodzącej zimy:

Upadek ekonomiczny królestwa polskiego, Litwy i krajów tak zabranych, jak i głębi Moskwy przybiera coraz większe rozmiary. Napływ nieustający fałszowanych rubli, odkryty świeżo w Białostockim, gdzie dzierżawcę dóbr xięcia Wittgensteina, niejakiego Nasse z Prus, złapano na gorącym uczynku wraz z jego synem (w. 1-6 d.),

a także przed przewidywaną wojną (s. 233), w której

alians romańskich ludów Hiszpanii i Włoch, z Francją, wesprzeć się chce na Austrji i Turcji, i na Szwecji, Norwegii i Dalmacji, ażeby cesarstwu moskiewskiemu i Prusom wydać wojnę, któraby rozstrzygła ostatecznie losy ludów europejskich (w. 2-5 g.).

Z kolei w numerze 11 za szkodliwy uznano prawdopodobnie fragment tegoż działu (s. 260) z ironicznym komentarzem redakcji na temat reakcji władz rosyjskich na kryzys gospodarczy:

Gdy wszystko co tylko można było dotąd zniszczyć z kapitałów istniejących w Polsce na Rusi, Litwie i w Moskwie zostało zniszczone rząd moskiewski uwzględnia potrzebę tworzenia nowych wartości i zezwala, ażeby się zawiązało Towarzystwo kredytu ziemskiego, z kilku milionami rubli, w Cesarstwie liczącem 380.000 mil kwadratowych i 70 milionów ludności. Na wielką pociechę niemieckich mędrców stanu, podjęte znów zostały, od lat sześćdziesiątych kilku toczące się układy co do ceł z carstwem moskiewskiem (w. 4-11 g.), 
wreszcie w numerze 12 - fragment dotyczący katastrofalnej sytuacji społeczno-gospodarczej w Rosji w porównaniu z innymi krajami:

Lecz cóż to wszystko znaczy wobec coraz okropniej i wyjawiającej się nędzy w carstwie moskiewskim. Obszernych krain ludność, jakiemi są gubernia Olonezka [Ołoniecka], Pens [Penza], Archangielska, Saratowa, Nowogrodu niema co jeść, masami w łachmany przyodziana, rzuca się do miast, rabuje gdzie może z głodu i rozpaczy i taborami całemi ciągnie jak szarańcza na Litwę i Ruś, tam zaś bieda także, a jak na Wołyniu i w Ruszczyźnie, głód, cholera i zaraza na bydło. — Na Sybirze w tobolskiej guberni, sybirska zaraza wydusza dziesiątkami tysięcy bydło i konie.

Na całym tym niezmiernym przestworze, ani doktora, ani ratunku, ani żadnych środków do zatamowania kataklizmu, jaki jedynie pod caryzmem wzrosnąć i do takiej okropności rozwinąć się może (w. 16-28 g.).

Aż 22 strony nakazano wyciąć z tomu 3 (1872) krakowskiego miesięcznika „Na dziś” poświęconego „literaturze, naukom, sztuce, gospodarstwu krajowemu, handlowi i przemysłowi”. Na większości z nich (s. 1-19) znajdowała się wierszowana gawęda Franciszka Gumowskiego Na zaścianku opowiadająca o przemianie narratora z „pustego młokosa” i „nieuka” w przykładnego młodzieńca, będącego wzorem dla otoczenia, który w nagrodę pozyskał rękę pięknej i uroczej Helenki. Zastrzeżeń cenzury nie wzbudziła oczywiście ta romantyczna historia, ale źródła i praktyczne skutki owej zmiany. Otóż pod wpływem snu bohater udał się na nauki do Krakowa i na skutek samego widoku miasta, a także przyswajanej wiedzy poczuł się innym człowiekiem:

Ach, panie, mój panie, w Krakowskiej Wszechnicy

Dopiero przejrzałem czem człeku być trzeba.

Tam panie poznałem, co kraj nasz, co gleba,

Co święte, co przeszłość, co dzieje, przyroda, [...]

Czem człowiek być winien dla braci, dla ludzi, [...]

A Wawel... o, panie, gdym stanął w katedrze,

Na grobie mych królów, na zamku mych panów,

Na górze tej świętej, na górze tytanów,

Myślałem, że pierś mi się z bólu rozedrze...

I chodzić począłem od trumny do trumny,

I wzrok swój rzucałem choć łzawy lecz dumny,

Na prochy mych ojców, na szczątki ich kości,

Na dawne trofea - i dawne wielkości...” (s. 11).

Po powrocie do rodzinnego domu młodzieniec zaczął prowadzić działalność oświatową wśród ludu, budząc w nim świadomość narodową:

W niedzielę i święta zebrawszy czeladkę, [...]

O dziejach ojczystych prawiłem im gadkę,

I wielkie z przeszłości stawiałem im wzory.

Toż najprzód o Skubie, o smoku w Wawelu,

Następnie o Lechu, Kruszwicy, Popielu,

O Piaście, o synu Łokietka - Kaźmierzu, 
O Czarnym Zawiszy — rozgłośnym rycerzu,

O Turkach, o Wiedniu, o Barze, o Sawie,

O Lwowie, Poznaniu, o Gnieźnie, Warszawie" (s. 12).

Natomiast okoliczną szlachtę nakłaniał do czynu i pracy:

Że nie iść $\mathrm{z}$ postępem, to trudna dziś rada,

Że gdy się nie wezmą do kunsztów, do pracy,

Do handlu, przemysłu — to zjedzą ich marnie

Zamorskie przybłędy, niemieccy żebracy,

I bieda kraj cały, kraj piękny ogarnie;

Ze gdy się nie zbliżą do ludu i z ludem,

To nikt nas nie dźwignie, chociażby i cudem" (s. 13).

\section{Pod wpływem ogólnej atmosfery także młodzież}

Kochała swą ziemię, tak jak się należy,

Jak święcie przystoi na synów rycerzy" (s. 14).

Jak się wydaje, przyczyną zakwestionowania s. 383 była znajdująca się tam notka poświęcona wydanej anonimowo broszurze Włodzimierza Spasowicza Polityka samobójstwa (Poznań 1872), dotyczącej opublikowanej pod pseudonimem broszury Kazimierza Krzywickiego Polska i Rossya w $1872 r^{53}$ Znalazła się w niej między innymi następująca opinia:

Zasadnicza idea b. członka Rady Stanu [pseud. Krzywickiego] nie może znaleść współczucia i uznania, nie tylko u Polaka, ale nawet u prawego Rosyanina, bo człowiek, który wyrzeka się swej narodowości, nie może zjednać dla siebie szacunku u nikogo.

W wypadku s. 405 zawierającej fragment obszernego listu do redakcji Poznańczyka (Franciszka Ksawerego Liskego?), polemizującego z poglądami Stanisława Tarnowskiego na temat Wacława dziejów Stefana Garczyńskiego („Przegląd Polski" 1872, nr 4) i jego słabej znajomości w kraju, cenzorowi chodziło prawdopodobnie o wzmianki o przemycie na ziemie polskie wydawnictw paryskich:

Nietylko ja, lecz i wielu pamięta bardzo dobrze dwa małe tomiki, drukowane w Paryżu, jakie pokazały się u nas w parę lat po rewolucyi. Były to poezye Garczyńskiego w licznych egzemplarzach nadesłane, a że małej objętości, więc i przemycić i przechować było je łatwo. Czytano je pilnie i pożądliwie, i mało kto lubujący się w poetycznej literaturze znalazł się coby ich nie znał. [...] znało Garczyńskiego tylu literatów i nie literatów, znało wielu miłośników poezyi, i nie wątpię, że gdyby był na niego popyt (mówiąc językiem handlowym), postaranoby się w Paryżu o nowe wydanie i przemycanoby je do kraju, gdzie wszystko, co było zakazane, było najbardziej pożądanem ${ }^{54}$.

53 O ile dwie edycje publikacji Krzywickiego dopuszczono do obiegu, o tyle broszurę Spasowicza w roku jej wydania zatrzymano (J. Kostecki, M. Rowicka, op. cit., t. 1, s. 94, 108).

${ }^{54} \mathrm{Na}$ decyzję cenzora wpłynęło też zapewne ocenianie Wacława dziejów (w tekście mylnie: Wacława, co odsyła do utworu Słowackiego) w kontekście kwestionowanych przez cenzurę innych utworów romantycznych: „Raz go przeczytawszy, zostawiano zapomnieniu; przy panu Tadeuszu, 
Wreszcie s. 426 zakwestionowano zapewne z uwagi na fragmenty Listów z Paryża A. de Large’a dotyczących sytuacji politycznej i społecznej za czasów II Cesarstwa, mogącej budzić szkodliwe skojarzenia z sytuacją Rosji, a zwłaszcza w zaborze rosyjskim:

bez pozwolenia policyi niewolno nam było zgromadzić się, wydawać uczty, a tem bardziej odbywać wieczory literackie. Przecięto nam związki rodzinne, starano się przytłumić wszystko, co człowieka uzacnia i podnosi. Miłość ojczyzny poczytano za grzech, a przynajmniej za coś niebezpiecznego; usiłowano zamknąć to najwznioślejsze uczucie w ciasnem i brudnem kole służalstwa lub przywiązania do dynastyi, szerząc tym samym samolubstwo po całym kraju.

Literatura poważna rozwijała się poza obrębem cesarstwa i skierowana była przeciw niemu. [...] Cesarstwo poniżając charakter narodowy paraliżowało publiczne wychowanie, a popychając umysły do dilettantizmu sceptycznego, oziębiało natchnienie. [...]

[Twórcy] Stali się [...] mniej więcej narzędziem rządu: cesarstwo wiele im jest obowiązane. [Ernest] Renan zaprzeczył bóstwa Chrystusowi, a [Hippolyte Adolphe] Taine obalił metafizykę. $[\ldots]$

[Z pokolenia, które zadebiutowało po $1865 \mathrm{r}$. Henri de] Rochefort[-Luçay] skazany na deportacyą do Nowej Kaledonii, ten człowiek, który swą Latarnia oświecił Francyą i rozbudził w narodzie miłość kraju, zostającego pod samowolnym rządem Napoleona III, a [Élisée] Reclus, poważany w całym świecie naukowym, dotąd jęczy w więzieniu.

\section{Z lwowskiego „Tygodnia Polskiego” (R. 8, 1881, t. 12) usunięto sześć frag-} mentów w pięciu numerach, z czego cztery z działu „Kronika Tygodniowa”. Połowa wszystkich materiałów dotyczyła udanego zamachu na cara Aleksandra II. Ze względu na objętość komentarzy, przytoczę tylko ich niewielkie fragmenty:

Pierwsze telegramy otrzymane w zeszłą niedzielę wieczór, lotem błyskawicy rozniosły się po mieście tak, że w poniedziałek rano, nie było stróża, nie było kucharki, któraby nie rozpowiadała o tem niezwykłym czynie Wszechmocnej Opatrzności. [...] Następca zabitego cesarza Aleksander III w przemowie swej do reprezentantów Rady państwa obiecał tak rządzić powierzonem sobie przez Boga państwem, żeby zasłużyć na miłość i przywiązanie ludu. Zgadzamy się na to i zauważyliśmy, iż pierwszy to jest monarcha rossyjski, który w ten sposób zaczyna pojmować swoje wysokie obowiązki. Nie potrzebnie tylko dodał, to zbyteczne wyrażenie: „podobnie jak mój ojciec" [...] dość, że pragnie miłości, pod którą zapewne i nasi rodacy zostający pod berłem rosyjskiem podciągnięci zostaną.

Nie możemy powiedzieć tego, żeby ten wypadek zabójstwa cara Aleksandra, na publiczności lwowskiej wywarł przygnębiające i smutne wrażenie. [...] wiadomem jest powszechnie, że zmiana osób wobec systematu nie ma żadnego znaczenia zwłaszcza w takiem państwie jak Rosja, i że szereg zamachów z taką uporczywością wznawianych przeciw Aleksandrowi II, miał więcej charakter osobistej zemsty, aniżeli ogólno państwowy. Zmarły cesarz o ile wiadomo, posiadał bardzo chwiejny charakter i stara kamarylla rządząca Rosją korzystała z tego, przeprowadzając pod jego firmą czysto osobiste interesa i cele - dowodem tego ostatnie powstanie nasze w r. 1863 i tak liczne a tak niepolityczne zarazem i okrutne egzekucje, zsyłki, mściwe gnębienia — niestety słabych przeciwników. Prawdziwa i pewna swej władzy siła surową jest ale zarazem wspaniałomyślną; tu

przy Słowackim, przy Nieboskiej komedii i Irydionie, tracił on bardzo; a niemniej przy pieśniach Janusza, które były we wszystkich ustach". 
zaś przeciwnie sztuczna groza miała zastąpić potęgę siły, a twardy i małoduszny upór - chciał nakazać dla siebie uszanowanie. [...]

Tyle zamachów jednak, kierowanych z upartą i niepohamowaną usilnością powinno raz przecie otworzyć oczy następcy zabitego cara, że jest pewna granica nawet dla samowładnego monarchy, której wobec głosu sumienia narodowego, tak lekko przekraczać i lekceważyć nie można (cały zakwestionowany fragment - nr 12, s. 93, szp. 1; szp. 2, w. 1-25 g.).

Tydzień już upłynął od czasu zamachu w Petersburgu, a dziennikarska rzesza całego świata karmi nas nieustannie szczegółami i drobnostkami tego faktu, jakbyśmy byli najwierniejszymi poddanymi Jego cesarskiej mości cara oswobodziciela, a nawet więcej niż poddanymi. [...] Doprawdy za wiele honoru dla tego wypadku, bo przypominamy sobie, że o sławnym ataku na Plewnę, prowadzonym pod okiem samego cara przypatrującego się z urządzonej oddzielnie werandy, daleko mniej pisano. A jednak dwanaście tysięcy dzielnego żołnierza położyło tam swoje głowy pod kartaczami Osmana paszy, na to tylko, żeby ubóstwianemu panu w dzień jego urodzin zrobić tę małą przyjemność i zdobyć okopy. Bataljony szły za bataljonami i wszystko to niknęło jak trawa na łące, podcięta kosą... Gazety coś tam wspominały o tych urodzinach, podały ogólną cyfrę poległych poczciwców, a potem zakopano ich we wspólnych dołach, posypując wapnem i cicho, sza - widowisko skończyło się... Nawet odważny książe Bismarck, także oswobodziciel ludów na drodze parlamentarnej, nie raczył odszukać między poległymi ukochanych Polaków, jak ich odszukał teraz pośród nihilistów moskiewskich, czychających na carów i porządek społeczny w Rosji (cały zakwestionowany fragment — nr 13, s. 101, szp. 1, w. 1-39 d.; szp. 2, w. 1-31 g.).

Poza tym cenzura nakazała usunąć liczący trzy zwrotki wierszyk M. Rodocia (Mikołaja Biernackiego) Satyra (nr 13, szp. 3, w. 24-36 g.):

$[\ldots]$

- Bo widzisz, zabili Cara.

Tak, kogo duma zaślepi

Boża dotyka go kara.

Teraz Polsce będzie lepiej...

— Wiem, wiem, już mi to mówili

I niania, i ciocia Hala...

Mamusiu! Czy to zabili

Już ostatniego Moskala?

Spośród dwóch pozostałych informacji o charakterze kronikarskim jedna brzmiała:

*Z okazji zatwierdzenia przez rząd Rosyjski testamentu św. p. [hr. Kajetana Jana Kantego Konstantego] Kickiego, który dość znaczny majątek zapisał na pożytek tak zwanych osad rolnych dla małoletnich przestępców w królestwie Polskim, chcemy zwrócić uwagę tak najwyższej władzy autonomicznej naszej, jako też i szerszego koła publiczności, na tego* rodzaju Instytucję tak dobrze i korzystnie tam prosperującą ${ }^{55}$ (nr 11, s. 85, szp. 2, w. 14-20 d.).

55 We wszystkich cytatach fragmenty zakwestionowane zaznaczam gwiazdkami. Oficjalna nazwa obdarowanej instytucji to Towarzystwo Osad Rolnych i Przytułków Rzemieślniczych (,instytucyja przez Rząd zatwierdzona”). Kicki chciał stworzyć fundację wspierającą wzorowe 
Druga była znacznie obszerniejsza i zawierała apel o nabycie rękopiśmiennych prac umierającego w „ciężkim niedostatku” Michała Modzelewskiego, który

za udział w działaniach 1846-1849 r. pociągnięty do odpowiedzialności, więziony lat kilka w cytadeli, zesłany został w r. 1854 na lat 4 do Sybirskiej katorgi do gub. Tobolskiej, gdzie pozostawał aż do r. 1858 [...].

Nastąpiły wypadki 1862 i 1863 r. [...] Rząd Narodowy mianował Modzelewskiego komisarzem, a następnie Naczelnikiem cywilnym Województwa Sandomierskiego. Że Modzelewski był już dawniej w Sybirze, więc go aresztowano, skazano znów na zesłanie [...]. Podczas choroby, za staraniem żony i pewnego pułkownika Polaka, zostającego w służbie moskiewskiej, uwolniony w roku 1864, powrócił na wieś, [...] pracował ciężko na kawałek chleba, aż śledzony i prześladowany przez Rząd moskiewski, musiał uchodzić z królestwa do Galicji (nr 15, s. 118, szp. 2, w. $10-18,25-51$ g.).

\section{Ostatni zakwestionowany fragment pochodził z zakończenia drukowanej} w odcinkach pracy Felicji z Wasilewskich Boberskiej O ksztatceniu charakteru:

Drugim jeszcze większem niebezpieczeństwem [poza „prądami nihilizmu”] grozi najmilszej ojczyźnie naszej to dziwne, dziś się szerzące, zobojętnienie dla jej przeszłości i przyszłości [...]

Wiem, iż są ludzie co w dobrej wierze uważają tę drogę za właściwą, pomyślną nawet dla narodu - ale znowu powiem, ci chyba nie znają natury ludzkiej. Może pierwsi pojednani z ciemięzcami, zachowaliby jeszcze trochę myśli o ojczyźnie, tę zgodę za środek tylko uważając. Ale gdyby parę pokoleń wyrosło zadowolonych z tego co jest, zbratanych z obcymi, starających się przypodobać władzcom; - zobojętnieliby oni powoli, zatracili cel dla środka, znikczemnieli by na drodze służalstwa i odstępstwa, i bezmyślnie, staliby się pomocnikami wrogom do zabicia tej naszej ukochanej, najmilszej ojczyzny, która żyje, dokąd my dla niej żyjemy, której przybytkiem nasze dusze, życiem: nasze usiłowania, by jej życie zachować. Niż taką straszną, powolną, ze spodlenia śmiercią umierać, o czyż nie lepszem byłoby wyginąć do ostatniego? Bezkarnie nikt nie schodzi na nikczemną apostazji drogę, cel nigdy nie usprawiedliwia poniżających środków, a nad wszystkie korzyści, nad każdy interes cenniejszą i wyższą jest godność.

Przebaczyć nieprzyjacielowi, nie szukać zemsty, to słuszne i chrześciańskie; ale przypochlebiać się katom wiekowym swych ojców, bratać się z nimi i rękę całować, choćby dla największych korzyści, nie potrafi ten, kto ma cokolwiek godności. Co byłoby poniżającem w stosunkach prywatnych, jest niem, stokroć jeszcze więcej w publicznych.

Strzeżmy godności narodowej, żyjmy i pracujmy z wytężeniem dla ojczyzny, lękajmy się nie strat i ofiar, ale znikczemnienia i służalstwa. Bądźmy godni ojców, godni tej matki Polski, co ludzkością i wolnością zespoliła liczne narody, co podbojów nie chciała, nie znała zdradnej polityki. Bóg da jeszcze żywot naszemu narodowi; lecz trzeba nam charakterów prawdziwych i nieugiętych, których nie uwiodą sofizma, ni ponęty i wygody osobiste (nr 14, s. 110, szp. 3, w. 1-19 d.; s. 111, szp. 1, w. 1-27 g.).

Najostrzej potraktowano jednak satyrycznego „Szczutka”. Spośród pięciu rozpatrywanych numerów cztery zatrzymano w całości, a w piątym zakwestionowano na s. 2 w szp. 1 (w. 1-14 g.) wierszyk Warszawskiemu Jenerat-Gubernatorowi:

gospodarstwa rolne, http://www.napisztestament.org.pl/aktualnosci/testament-hrabiego-kajetana-kickiego/ [dostęp: 16.01.2020]. 
Żądasz panie jenerale,

Aby naród cały

Jak ty, przeszedł na moskale,

Rzucił ideały.

By zapomniał o ojczyźnie,

O wierze, przyszłości,

A szukał pociechy w szyźmie

I w carskiej miłości.

Pomysł ten, zaręczam panu,

Nie zwabi Polaków,

Świadcząc, że twój rozum stanu

Nie wart funta kłaków.

2.4

Upór niektórych importerów czasem się jednak opłacał. Mimo zatrzymywania całych przesyłek lub/i tylko warunkowego dopuszczania innych, pozostałe (lub ich części) trafiały jednak do obiegu. Tak było w wypadku lwowskiego „Kwartalnika Historycznego”. Co prawda w sprowadzonym najpierw zeszycie 1 rocznika 1 (1887) cenzura kazała usunąć trzy strony, na których znalazły się fragmenty recenzji Waleriana Kalinki z książek: Edwarda Likowskiego Rokowania poprzedzające Unię brzeska, Kraków 1886 (s. 117-118) oraz Zygmunta Szczęsnego Felińskiego Paulina, córka Ewy Felińskiej, Lwów 1886 (s. 129) ${ }^{56}$, ale w trzy przesyłki z kolejnych lat (łącznie osiem numerów) nie ingerowała. O zakwestionowaniu wspomnianych stron zadecydowały z pewnością między innymi takie opinie, jak:

Uznanie władzy papieża było lekarstwem, które nie usuwało od razu choroby, tylko długie jego używanie mogło Ruś przywołać na powrót do zdrowia. Głównym złem cerkwi ruskiej był duch schizmy, to jest panowanie świeckich w Kościele. [...] Trzeba było dłuższego czasu za nim kark księży ruskich wiecznie nachylony mógł się odprostować, zanim w ich duszy święte dla papieża posłuszeństwo zajęło miejsce hańbiącej dla świeckich uległości, i za nim skutkiem tego uwierzyli, że każdy z nich ma missyą od Boga, wyższą nad wszystkie ludzkie potęgi (s. 117, w. 13-16 d., w. 1-3 d.; s. 118, w. 1-2 g.),

\section{czy}

Znanym jest list Seneki [Młodszego, zw. Filozofem] do Luciliusza [Caiusa Luciliusa Iuniora] (XIV), w którym mędrzec pogański zdumiewa się nad spokojem, z jakim ofiary Nerona swe niewysłowione przyjmowały boleści. Zdaje się nam, że uczciwy Rossyanin czytając Paulinę doznałby tego samego wrażenia, jakiemu uległ w owych czasach literat rzymski, zapomniałby, że to Polacy, a widziałby przed sobą istoty szlachetne, najniesprawiedliwiej dręczone (s. 129, w. 19-26 g.).

56 Obu cenzura nie dopuściła do obiegu (J. Kostecki, M. Rowicka, op. cit., t. 1, s. 424, 450). 
Podobnie było w wypadku lwowskiego miesięcznika „Lud”. Choć już w zeszycie 1 rocznika 1 (1895) zakwestionowano jedną stronę „Słowa wstępnego”, przy czym cenzorowi chodziło zapewne o następujący fragment:

Ważniejszym o wiele [od względu praktycznego] jest to, co stanowi niespożytą siłę ludu i zarazem tak ważny czynnik w życiu każdego narodu. To jest owa rodzimość i odporność ludu, z których pierwsza jest źródłem, ożywiającem ducha narodowego i utrzymujacem go w jego czystości i nieskazitelności, druga twierdzą i stróżem jego życia i jego tradycyi. Historya poucza nas, że naród nie zginie, jak długo lud jego żyje, który zdolen jest ożywić obumarłe członki ciała narodowego i wlać nowe życie w dzieła jego umysłowej pracy. Kiedy kosmopolityczne prądy biją w tę twierdzę narodowości, niech będzie świętem staraniem każdego otoczyć opieką tę twierdzę i wzmocnić ją [...] (s. 3, w. 6-17 d.),

to w badanym okresie sprowadzono jeszcze 15 innych numerów pisma, z czego tylko w dwóch zakwestionowano łącznie 25 wersów. W zeszycie 1 rocznika 6 (1900) w tekście Jana Witorta Filozofia pierwotna. (Animizm) nakazano usunąć fragment dotyczący zwyczaju stypy:

kasza ta po rosyjsku nazywa *się „kutja”. Na stypie, a niekiedy nawet w cerkwi, spożywają ją; na stypie muszą być koniecznie bliny, jedzą je, zapijając wódką, śpiewając „So światymi upokoj” i bijąc pokłony! Scena to wstrętna, którą widziałem kilka razy na północy i na Syberyi. Stypy do niedawna należały do koniecznych obrzędów pogrzebowych, nawet wśród warstw wyższych, co do dziś dnia jest koniecznością w Rosyi* (s. 26, w. 1-7 d.),

a w zeszycie 1 z rocznika 10 (1904) w tekście Michała Janika Flisacy fragment, w którym znalazły się między innymi następujące informacje:

flisacy nie zawsze mieli wyrobione *uczucia narodowe. [...] Miał jednakże Ulanów ${ }^{57}$ swoich żołnierzy w obu powstaniach, a w niektórych rodzinach przechowywano w sposób prawdziwie wzruszajacy polskie tradycye. W r. 1863 oddawali flisacy przysługi powstańcom w roli szpiegów, do czego zatrudnienie bardzo się nadawało, a gdy ogłoszono w Galicyi stan oblężenia, wielu powstańców zręcznie w Ulanowie ukrywano i ratowano. Ogólnie powiedzieć można, że mimo wszystko dawniej i dzisiaj uczucia narodowe żywszem biły tętnem w miasteczku flisackiem, aniżeli w innych zakazanych kątach, czyli t. zw. miasteczkach galicyjskich* (cały zakwestionowany fragment - s. 10, w. 1-18 g.).

Także w wypadku „Przewodnika Naukowego i Literackiego” (dodatku do „Gazety Lwowskiej”) cenzura od początku miała wątpliwości. Gdy jako pierwszy trafił do niej w 1873 roku zeszyt 2 rocznika 1, stwierdzono, że co prawda

Ten numer pisma nie zawiera nic nagannego. [Jednakże] P. Wołoczaninow przedstawił go do rozpatrzenia Komitetu z powodu tego, że jakiś Łoziński uczestniczył w ostatnim polskim buncie.

Komitet postanowił: dla uzyskania informacji o osobie redaktora omawianego pisma, Władysława Łozińskiego sporządzić przedłożenie do Zarządu Głównego do spraw Druku ${ }^{58}$,

57 Miasto położone u ujścia Tanwi do Sanu. Obecnie w województwie podkarpackim (powiecie niżeńskim).

58 AGAD, WKC, sygn. 34: PP 1873, nr 8 z 5 marca, k. 45 v. Losów owego przedłożenia nie znam. Z wypadkami cenzury podmiotowej spotkałem się zaledwie kilkakrotnie i to tylko w latach 70. (J. Kostecki, Rosyjska praktyka kontroli..., s. 113-114). 
lecz w latach późniejszych sprowadzono jeszcze 25 numerów pisma, z których 16 pozwolono rozpowszechniać, a tylko pięć zatrzymano (R. 13, z. 12 i R. 14, z. 1-4) oraz cztery dopuszczono do obiegu warunkowo. Jeszcze w 1873 roku tenże

P. Wołoczeninow przedstawił do rozpatrzenia Komitetowi tylko jedno miejsce, w zeszycie 6, s. 488 (w. 7-11 g.), w którym wspomniano o wydarzeniach w Warszawie 1863 roku. Miejsce to, według P. Cenzora powinno być usunięte ${ }^{59}$.

Fragment ten pochodził z recenzji rozprawy Stanisława Koźmiana Żywot i pisma Konstantego Gaszyńskiego („,Roczniki Towarzystwa Przyjaciół Nauk Poznańskiego", t. 7), pióra Xawerego Liske, Władysława Kazimierza Wójcickiego oraz Romana Pilata, i brzmiał następująco:

Wieść o wypad*kach warszawskich wstrząsnęła nim [Gaszyńskim] potężnie i obudziła znowu zamiar powrotu do kraju, który jednak z powodu nieszczęśliwego obrotu sprawy nie przyszedł do skutku. Okropnym ciosem była dla niego wiadomość o śmierci matki, która zamordowaną została. Pod wpływem tych ogólnych jakoteż osobistych nieszczęść rzucił na papier* zbiorek poezyi: Kilka pieśni dla kraju (1864).

Kolejne dwa wersy zakwestionowano w artykule dr. J. [Antoniego Józefa Rollego?] Materyat do objaśnienia początku konfederacyi Targowickiej i drugiego podziału Polski drukowanym w zeszytach 10 i 11 rocznika 3 (1875). Pierwszy z nich brzmiał: ,[...] najprzód indygena*tami tak szafował Stanisław August, że nie tylko Potemkinowi [Grigorijowi Aleksandrowiczowi Potiomkinowi] go nadał* [...]” (z. 10, s. 967, w. 7 d.), drugi zaś: „Książę [Potiomkin] party przez Katarzynę, widząc nad *sobą przewagę ostatniego jej kochanka Walerjana [Aleksandrowicza] Zubowa, wyjeżdżał* niechętnie [...]” (nr 11, s. 1063, w. 20 g.).

Ostatni, najobszerniejszy z zakwestionowanych fragmentów to początek historycznego szkicu Rollego Niedoszłe legiony. Opowiadanie z przeszłego wieku (R. 4, 1876, z. 10, s. 947-960) poświęconego próbom wykorzystania przez carat (najpierw Potiomkina, potem Michaiła Nikiticza Krieczetnikowa) wojskowych polskich z terenów zagarniętych w czasie kolejnych rozbiorów, a także działaniom „garstki nieprzejednanych” (w tym brygadiera Ksawerego Franciszka Łaźnińskiego), którzy przeszli na drugi brzeg Dniestru i później wzięli udział w insurekcji kościuszkowskiej, wreszcie emigracyjnym losom niektórych powstańców.

Pewien sukces udało się osiągnąć nawet jezuickim „Głosom Katolickim” z Krakowa. Choć w 1901 roku zatrzymano dwa numery z lat 1900 (O wyborach) i 1901 (Sprawiedliwość i miłosierdzie), to w 1904 roku dopuszczono do obiegu nr 44 rocznika 4 ( $O$ mszy św., cz. 6).

Równie mało spektakularne efekty przynosiły wysiłki wejścia na rynek zaboru rosyjskiego krakowskiego miesięcznika „Przegląd Polski”. W latach 70.

59 AGAD, WKC, sygn. 34: PP 1873, nr 23 z 25 czerwca, k. 108-108 v. W wykazach miesięcznych informacja o zakwestionowaniu całej strony. 
(?-1876) zatrzymano pięć kolejnych przesyłek (łącznie dziewięć numerów z trzech roczników: $7,9,10)^{60}$, ale w 1881 roku warunkowo dopuszczono zeszyty 10 i 12 z rocznika 15 . W pierwszym wypadku zakwestionowano: dwa passusy z tekstu Tarnowskiego Ksiąze Roman Sanguszko ${ }^{61}$, gdzie autor pisał o nim, że

znosił poniewierkę i prześladowanie i urąganie [...], podobny był do tych wielkich dusz polskich, co niezłomnością swoją i gotowością na wszystko czynią zadosyć za rokosze i konfederacye, za konszachty i kapitulacye XVIII wieku. [...] prawić i śpiewać będą po wiekach o kniaziu co szedł na Sybir do drąga przykuty, i na Kaukazie dźwigał karabin, co w domu zostawił starą matkę i małą córkę-sierotę... (s. 134, w. 11-18 g. oraz s. 135, w. 8-10 g.),

a także cztery wersy z pracy Hugo Zatheya Boleslav Jablonsky. (Karol Eugeniusz Tupy) ${ }^{62}$, gdzie znalazło się następujące stwierdzenie: „Moskale, o których mówiło się niegdyś, że lud jest poczciwy, a rząd zły i wrogi zarówno nam, jak swoim, stali się nam dziś gorszymi może wrogami, niż ich carowie" (s. 136, w. 11-14 d.), a także obszerny fragment (s. 143-150) Przegladu politycznego Aleksandra Szukiewicza, poświęconego zamachowi na Aleksandra II. Obejmował on szczegółowy opis samego zdarzenia, ale przede wszystkim spekulacje dotyczące sił politycznych stojących za zamachem, analizę manifestu Aleksandra III i przewidywania na temat zamierzeń nowego cara, zwłaszcza w stosunku do Finlandii i ziem polskich oraz relacji z Prusami. Szukiewicz pisał między innymi:

Nihiliści mieli tylko powierzoną sobie rolę skrytobójców; następstwa mogące wynikać z carobójstwa, zastrzegli sobie spiskowcy z innego obozu.

Rachowano zapewne na to, że następca tronu wejdzie na inną drogę, że pod grozą bomb, które ojca zabiły, że wobec pół głosem objawianych żądań zmiany systemu rządowego, naznaczy on pierwsze dni swego panowania manifestem zwiastującym niejakie swobody [...], stworzy formy organizacyi państwa zbliżonych do tych, jakie w innych państwach Europy istnieją. Nie stało się to w pierwszej chwili wstąpienia na tron Alexandra III; nie stanie się zapewne rychło, skoro manifest cara żadnej pod tym względem nie budzi nadziei [...]. Car nie przestanie być „,samodziercą”, zatem nie ma mowy o zmianie rządów autokratycznych na rząd konstytucyjny. [...]

Pod względem Polski spotkały się z sobą w wspólnym interesie organa rządu pruskiego z podżegaczami moskiewskiej publicystyki. Tym ostatnim, propagującym pod firmą panslawizmu panowanie żywiołu rosyjskiego we wszystkich ziemiach słowiańskich, szło o to przede wszystkiem, aby ziemie polskie nie uzyskały zwolnienia z pod ucisku, w ostatnich szczególnie latach zaprowadzonego na zagładę narodowości polskiej i religii katolickiej, zwłaszcza że rząd rosyjski jeszcze za życia Aleksandra II uznał potrzebę zgody z Stolicą Apostolską, jako najwyższą wyobrazicielką prawa Bożego spółczesnego ładu i władzy (s. 146, 148, 149).

60 Swą decyzję w stosunku do z. 9 z rocznika 7 uzasadnił po prostu: „W obecnym zeszycie tego czasopisma wrogiego w całości Naszemu Rządowi — znajduje się znaczna liczba miejsc podlegających wykluczeniu" (AGAD, WKC, sygn. 34: PP 1873, nr 20 z 4 czerwca, k. 93-93 v.).

61 Chodzi o urodzonego w 1800 roku Romana Stanisława Adama Sanguszkę, uczestnika powstania listopadowego, zesłanego do Tobolska, a potem przeniesionego na Kaukaz. Tam przymusowo wcielony jako szeregowiec do wojska, został poważnie ranny; w 1845 roku formalnie zwolniony.

${ }^{62} \mathrm{Z}$ pochodzenia Czech, urodzony w 1813 roku, ksiądz katolicki, poeta, 34 lata spędził w Krakowie. 
W zeszycie 12 ingerencje obejmowały jeszcze większe partie tekstów. Przede wszystkim zakwestionowano w całości (s. 317-356) dokończenie artykułu Andrzeja Józefczyka Wspomnienie ubiegłych lat. (Przyczynek do historyi spisków $w$ Galicyi), byłego studenta Uniwersytetu Lwowskiego i uczestnika spisków, opisującego śledztwo i swój pobyt w więzieniu, a w tle — działalność w drugiej połowie lat 30. i na początku 40. takich organizacji, jak zwłaszcza Młoda Sarmacya (potem Sprzysiężenie demokratów polskich) i Synowie Ojczyzny. Nakazano też usunać dwa fragmenty Przegladu politycznego wspomnianego Szukiewicza (s. 447-453, 459), gdzie kontynuował on swe analizy dotyczące manifestu Aleksandra III, okólnika nowego ministra spraw wewnętrznych Nikołaja Pawłowicza Ignatjewa, a także Rosji w ogóle, pisząc między innymi:

Rosya nie jest jeszcze narodem, lecz zbiorem ludów różnych językiem, obyczajami, religią [...] w tem państwie zrosłem z podbitych ludów, utrzymywanych w łączności władzą samodzierczą i wojskiem, niema ani wspólności interesów i potrzeb, ani moralnego poczucia ojczyzny [...]. Rosya despotyzmem i centralizacyą doszła do jedności państwa, które olbrzymiem ciałem swojem przygniotło wolność Europy [...] rozbicie społeczne i zgnilizna moralna społeczeństwa nie wychodziły na jaw po za granice, wewnętrzne zaś skargi i sarkania tłumione były przemocą lub duszone w cytadelach i na Sybirze. Tu szukać należy przyczyn powstania nihilizmu [...]. Lekarstwa na nihilizm nie przyniesie manifest nowego Cara, ani okólnik nowego ministra spraw wewnętrznych...

Najnowszym objawem buntu społecznego w Rosyi [...] są napady na żydów w południowej Rosyi (s. 450-451).

Ostatni fragment to niemal cały dział „Nowe książki” (s. 461-464), w którym zaprezentowano między innymi Księgę pamiątkowa w 50-letnia rocznice powstania w r. 1830 (Lwów 1881) — ,jedną z najpiękniejszych pamiątek ostatniej prawdziwie narodowej wojny" (s. 461), broszury: Polska i Rosya wobec ostatnich wypadków (Lwów 1881) — „skreślenie stosunku Polski do Rosyi, wskutek śmierci Aleksandra II, i zarodów możliwej między Polską i Rosyą zgody” (s. 463), Gustawa Roszkowskiego $O$ środkach międzynarodowych przeciwko nihilistom (Lwów 1881) — z konkluzją „Niech Rosya sama troszczy się o owoc, który wydała” (s. 463); Switto. Pysmo dla Naroda — ,redagowane w dobrym pojednawczym duchu, a drukowane łacińskiemi czcionkami [...]" (s. 463), Stanisława Tomkiewicza Pieśń z pieśni miłości (Kraków 1881) — z widocznym wpływem Zygmunta Krasińskiego, z którego przebija między innymi ,wiara w ojczystą sprawę” (s. 464) ${ }^{63}$.

Licznymi niepowodzeniami nie zrażano się w wypadku dwóch pism specjalizujących się w drukowaniu kazań. Spośród 19 sprowadzonych w latach 1898-1903 zeszytów ukazujących się trzy razy w roku krakowskich „Kazań i Szkiców Księży Towarzystwa Jezusowego", aż 17 cenzura zatrzymała w całości (t. 1, z. 1-3; t. 2, z. $1-3$; t. 3, z. 2 ; t. 4, z. 1-3; t. 5, z. 1-3; t. 6, z. 1-3; t. 7, z. 1). Dragomirecki,

${ }^{63} \mathrm{Z}$ publikacji tych w badanym okresie sprowadzono do zaboru rosyjskiego tylko ostatni utwór. Cenzura dopuściła go do obiegu w całości. 
który rozpatrywał numery tomów 5-7, zwrócił uwagę, że jest to „Wydawnictwo jezuitów, w którym mówi się o prześladowaniach w Rosji wiary katolickiej” i jako przykład podał „str. 353-375, zeszyt 2 i in.”, a zakończył konkluzją: „Wszystkie wyżej wskazane broszury podlegają zakazowi na podstawie rozporządzeń Zarządu Głównego do spraw Druku z 10 kwietnia 1869 r. i 20 kwietnia 1872 r. o No $1630 " 64$. Jednakże w 1899 roku cenzura dopuściła do obiegu zeszyt 1 tomu 3, a w 1900 roku - warunkowo zeszyt 3 tomu 3. W tym drugim wypadku zakwestionowano akapit (s. 376, w. 1-10 d.; s. 377, w. 1-8 g.) ze Szkicu kazania o papiestwie Mariana Morawskiego dotyczący relacji Kościół-państwo:

Leon XIII dopełnia, co Pius w swem działaniu musiał pominąć: wchodzi w układy z panującymi, z rządami - bo i to i tamto do papieskiego urzędu należy i do życia Kościoła potrzebne. Wdaje się, jak mówią, w politykę, ale w politykę, której jedynym objektem jest interes dusz. Boleć to musi czasem ludy, kiedy im inną drogę wskazuje niż chciały, ale prawda czasem boleć musi. [...] Kościół stać musi ponad partyami. U nas wrzaski powstają na samą wieść, że się układa z caratem - a przecież czy nie on jeden trzyma w szachu tę brutalną potęgę? Bracia nasi przekonali się już o tem. W szczegółach tej polityki upatrzyć możemy wiele niepowodzeń, ale w rezultacie się ona udaje; sprawia w każdym razie, że Papiestwo jest ogromnie szanowane — w czem cały katolicyzm uczestniczy.

Lepsze efekty przyniósł upór w wypadku prób wprowadzenia do obiegu poznańskiego dwumiesięcznika „Biblioteka Kaznodziejska”. W latach 1880-1895 sprowadzono około 40 zeszytów, w tym w całości zatrzymano tylko dziewięć. Trzy pierwsze z nich rozpatrywał Christofor Władimirowicz Emmausski. Uzasadniając swe negatywne decyzje w stosunku do zeszytu $6 \mathrm{w}$ tomie 1 i zeszytu 1 w tomie 6, stwierdzał on:

W V tomie tej „Biblioteki” na str. 20 i 21, w jednym z kazań zamieszczone są, między innymi, wyrażenia patriotyczne i utyskiwania nad aktualnym położeniem Polski, a w tomie VI, w wielu miejscach, znajdują się wzmianki o prześladowaniu katolicyzmu w Rosji, bezpośrednie i pośrednie zarzuty w stosunku do prawosławia i gorące wezwania do pieniężnych ofiar na rzecz katolickich towarzystw misjonarskich w Chinach ${ }^{65}$.

\section{Natomiast w wypadku zeszytu 3 tomu 6 zwracał uwagę, że}

W zeszycie tym znajdują się zaproszenia do ofiar na rzecz katolickich towarzystw misjonarskich, znajdujących się pod głównym zarządem „Kongregacji Rozkrzewiania Wiary”, a także i samego papieża. Oprócz tego spotyka się nieprzystojne opinie o w ogóle chrześcijanach niekatolikach $^{66}$.

W zeszytach warunkowo dopuszczanych do obiegu z reguły kwestionowano całe strony, tylko dwukrotnie poprzestano na wskazaniu poszczególnych wersów. Przykłady te są o tyle interesujące, że we fragmentach tych wydawcy i tak opuścili

\footnotetext{
64 AGAD, WKC, sygn. 44: PP 1903, nr 18 z 13 maja, k. 197 v.

65 AGAD, WKC, sygn. 37: PP 1886, nr 8 z 20 lutego, k. 29 v.

66 AGAD, WKC, sygn. 37: PP 1886, nr 27 z 3 lipca, k. 113-113 v.
} 
niektóre słowa (prawdopodobnie — „Rosja”) ${ }^{67}$. Oba dotyczyły prześladowania Kościoła katolickiego. W tomie 3 (z. 9-11) z 1880 roku cenzor nakazał usunąc fragment Kazania II. na Niedz. Ostatnia po Światkach. Obrzydliwość spustoszenia:

Przez miejsce święte należy rozumieć Kościół Chrystusowy, to jest Kościół katolicki; albowiem on jest oblubienicą bez zmazy i bez zmarszczek. Do tego miejsca św. wciska *się obrzydliwość spustoszenia przeto, iż prawa Kościoła obalają, a dzieci tej Matki Kościoła uwodzą. Widzieć to każdy i doczytać się może do woli z pism publicznych, iż tak jest rzeczywiście, iż święte prawa kościelne nie są szanowane, lecz owszem deptane zawzięcie. Rzućcie okiem na Włochy, na Niemcy, na..., patrzcie na inne państwa: wszędzie usiłują Kościół boży służebną niewiastą uczynić i robić z nim co się tylko podoba. Zabierają mu wszystko, do czego ma najwyraźniejsze prawo, co mu wśród najuroczystszych przekazano zobowiązań; prześladują kapłanów, zamykają szkoły, zamykają jego zakłady zbawienne, a nawet własnością jego, majątkiem kościelnym rozporządzają jak najsamowolniej. Tym sposobem wdzierają się w samo wnętrze życia kościelnego i krępują jego ręce i nogi. Co się tyczy dzieci* Kościoła, to one na różnorodne wystawione pokusy i nader często padają ofiarą zwodzicielstwa (s. 669 , w. 1-9 d.--s. 670, w. 1-5 g.).

\section{Natomiast w tomie 4 - fragment części 3 Kazania na Poniedziałek Wielkan. Panie zostań z nami!}

Obejrzyjcie się naokoło siebie, a nie wiele znajdziecie krajów, któreby nie powstawały wrogo przeciw Ko*ściołowi, w większej części wre prześladowanie. Jedni działają otwarcie, drudzy potajemnie, jedni z brutalną przemocą, drudzy z zdradzieckim podstępem; jedni wtrącają Biskupów i kapłanów do więzień, drudzy na drodze praw niesprawiedliwych — wszyscy zaś w ten lub inny sposób biją zawzięcie na Kościół i na Wiarę Kościoła. Wspomnijcie na..., na..., na Włochy, Szwajcaryą, Francyą i inne państwa z tej i z tamtej strony oceanu. Ileż to razy wyrażał Ojciec św.* w swych uroczystych przemówieniach żałość swoję z tego powodu [...] (s. 275, w. 8-15 g.).

Największych ingerencji dokonano w innych zeszytach (3 i 4) wspomnianego tomu 3 (z 1880 roku), gdyż zakwestionowano w nich cztery fragmenty liczące łącznie 43 strony. Były to kazania biskupa Josepha Georga von Ehrlera na kolejne niedziele po Wielkanocy, mające pokazać przyrodzone cechy Kościoła katolickiego i udowodnić, że tylko on jest prawdziwy: Kazanie I. na Niedzielę I. po W. Nocy. O jedności Kościoła (s. 246-256), Kazanie I. na Niedzielę II. po W. Nocy. Katolickość Kościoła (s. 263-274), Kazanie I na Niedzielę III. po W. Nocy. Świętość Kościoła (s. 281-290) oraz Kazanie I. na Niedzielę IV. po W. Nocy. Apostolskość

67 W podobnych kategoriach należy chyba rozpatrywać losy tomu 8 „Biblioteki...”. Do obiegu dopuszczono bowiem jego wydanie drugie. Może to świadczyć o tym, że wydanie pierwsze wydawcy spreparowali w ten sposób, by tom nie budził zastrzeżeń urzędu kontroli. O rozmaitych obronnych praktykach wydawców w tym czasie zob. M. Rowicka, Wydawnicze i cenzuralne losy twórczości Adama Mickiewicza w okresie zaborów, Warszawa 2014; J. Kostecki, Warianty wydawnicze jako reakcja na ingerencje cenzury rosyjskiej w II połowie XIX w., [w:] Trzy pokolenia. Pamięci Profesor Janiny Kulczyckiej-Saloni, Warszawa 1998, s. 161-170. 
Kościoła (s. 296-306). W tekstach tych nie wspomina się co prawda o prawosławiu $^{68}$, ale czytamy w nich między innymi:

Jedność w rozmaitości, — oto prawo ładu i piękna! Jedność, która ma się uwydatnić w odszczepieniu, rozdzieleniu, nieładem jest, — zamieszaniem jest, — rozdarciem jest. [...] Jeżeli więc Kościół Chrystusowy jeden tylko jest i jeden tylko być może, tedy pytam się: Któryż to zpośród tylu rozmaitych religijnych społeczności, jest kościołem prawdziwym, założonym przez Jezusa Chrystusa? I odpowiadam: Jest nim — nasz Kościół, Kościół święty, katolicki, albowiem on to jak najwybitniej i on jedynie nosi na sobie onę cechę jedności (s. 251, w. 8-11, 17-22 g.).

Papież jest ogniskiem — centrum jedności, jest onym łukiem, który całą budowę Kościoła spaja i pojedynczym jego częściom moc daje i trwałość. [...]

Tam gdzie od tej jedności kościelnej odstąpiono, musiał się Kościół Jezusowy rozpaść na territorialne (krajowe) kościoły, które się całkiem zdały na łaskę i niełaskę rządów, aby się przed zupełną zagładą ratować. Wyparłszy się prawowitej władzy, dostali się pod ciężkie jarzmo obcego panowania (s. 255, w. 15-18 g., 6-11 d.).

Wszystkie insze chrześciańskie i niechrześciańskie wyznania nie mogą się zwać katolickiemi, powszechnemi [...]. Liczba chrześcian wschodnich, niekatolickich wynosi 75 milionów [...], a [...] wszystkie sekty razem nie dochodzą liczby 200 milionów katolików (s. 269, w. 5-11 g.).

Owóż i my przyczyniajmy się modłami naszemi i wspieraniem prac misyjnych Kościoła do tego, żeby ten Jeden Kościół Chrystusowy dokonał co rychlej powołania swego: żeby był jeden Pasterz i jedna owczarnia (s. 274, w. 10-13 g.).

Kościół nasz nazywamy przy każdej sposobności — świętym [...]. Tak mówili zawsze Apostołowie i Ojcowie święci. Lecz czyż mamy prawo do tego? Owóż nie tylko mamy prawo, lecz mamy prawo wyłączne (s. 282, w. 16-21 g.).

[...] Kościół nasz jest prawdziwym Kościołem, założonym przez Chrystusa Pana; [...] tylko ten jeden Kościół nasz ma prawo zwać się świętem Ciałem Chrystusowem i jego świętą Oblubienicą. Ztad wynika dalej, że tego tytułu musimy każdemu innemu wyznaniu odmawiać (s. 287, w. 10-14 g.).

Owóż Kościół rzymski może z największem prawem zwać się apostolskim, albowiem on sam jeden ze wszystkich od Apostołów założonych, do dziś dnia istnieje, podczas gdy wszystkie inne z kolei wieków do szczętu zniszczały (s. 300, w. 16-19 g.).

My zaprzeczamy, żeby poza Kościołem był jaki urząd nauczycielski, było namaszczenie jakie i moc udzielania Sakramentów św.; każdy sługa jakiegobądź wyznania nie jest niczem więcej, jeno prostym człowiekiem, który w swojem własnem imieniu i własną swoją mocą odprawia czynności (s. 305, w. 12-16 g.).

68 Na pojawienie się tego terminu w tekście oryginalnym wskazują jednak opuszczenia w następujących zdaniach: „Poza Kościołem Chrystusowym widzimy wieczne swary i kłótnie co do nauki; albo też jest nim jedność, jak np. w kościele... ale jedność martwa — jest martwota, — mumia jedności, albowiem tam rozkazy potentatów świeckich zabijają wszelki objaw życia kościelnego" (s. 253, w. 8-12 g.). „Gdzie indziej, n.p.... mimo pogańskich iście okrucieństw i prześladowań, nie zdołano wytępić katolictwa [...]” (s. 268 w. 12-13 g.). Zob. też przypis 67. 
Poza tym w jednym z kazań (s. 286, w. 15-16 g.) autor wspominał też „naszego św. Józefata Biskupa i Męczennika”, postać konsekwentnie usuwaną ze wszystkich tekstów rozpatrywanych ówcześnie przez cenzurę.

W rozpatrywanych pięć lat później (w 1885 roku) pięciu zeszytach (1-5) tomu 5 ingerencji było co prawda więcej (siedem), ale łącznie zakwestionowano tylko 18 stron, gdyż nakazywano usuwać nie całe kazania, lecz tylko ich fragmenty. Na przykład opiniując zeszyt 1, Friedrich Aleksandrowicz Fecht

zaproponował dopuścić [go] do obiegu wśród publiczności z wykluczeniem str. 28 i 29, gdzie znajdują się niestosowne aluzje do położenia Kościoła rzymsko-katolickiego w tutejszym kraju ${ }^{69}$.

Była to prawie cała część druga: Kazania na Trzech Króli. Płonne zmysty Heroda, podpisana J. Bussl. Cenzorowi chodziło jednak prawdopodobnie o następujący fragment podsumowujący opis działań Heroda, który kazał „wymordować wszystkie pacholęta od lat dwóch i niżej”, by tylko zabić „Dzieciątko Jezus”:

Taki owóż pierwowzór prześladowców Kościoła. Nie kłopocą się oni nigdy o środki do celu: zarówno im dobry podstęp, obłuda, jak i gwałt jawny. Co tylko się da wynaleźć i wymyślić ohydnego, to rzucają śmiało w twarz Kościołowi. [...] Upadek lub winę osób kładą na karb całemu stanowi, i z miną obłudną świętoszka wołają: Patrzcie, ile zgnilizny w Kościele katolickim; państwo powinno w to wejrzeć.

A jeżeli nie podobna zwalić winy na Kościół, tedy usiłują podać w nienawiść instytucyje jego i osoby; tedy z największą zaciekłością uderzają właśnie na najżywotniejsze członki Kościoła, zowiąc ich zaślepieńcami fanatyzmu; tedy ci obłudnicy wołają: O kościele katolickim nie możemy nic złego powiedzieć, my występujemy przeciw Jezuitom i ultramontanom. Nie dość na tej obłudzie. Z drugiej strony ci zawzięci wrogowie Kościoła pod obłoki wynoszą i hojnie darzą zdradzieckie i buntownicze dzieci tego Kościoła [...] (s. 28, w. 4-8 d.; s. 29, w. 3-14 g.).

W pozostałych zeszytach zakwestionowano zakończenie Kazania na Poniedziałek Wielkanocny. Trzy wieczory, także podpisanego Bussl. (s. 228), ostatni fragment Kazania na niedz. VI. po W. Nocy. Żotnierstwo nasze (s. 269-271), koniec Kazania na Wniebowst. Pańskie. Kto może spodziewać się Nieba? (s. 277-278), fragment Kazania na niedziele Świateczna. Odnowienie świata Adriana Gretscha (s. 290), niemal całe Kazanie na Niedzielę IV. po Światkach. Obfity połów, podpisane T. (s. 333-339), a także dwa fragmenty Kazania na uroczyst. św. Piotra i Pawła. Obowiąki katol. względem Kościoła prawdopodobnie wspomnianego już Ehrlera (s. 350, 354). Większość tych tekstów poświęcona była w mniejszym lub większym stopniu zadaniom wiernych w życiu doczesnym, a więc przede wszystkim: kład:

— modlitwom do Chrystusa o pomyślność Kościoła katolickiego, na przy-

Zostań z tą parafiją, odwracaj od niej wszelkie szkody i przygody, albo spraw przynajmniej, by z Tobą chętnie cierpiała i ofiarowała. Pozostań osobliwie z Ojcem naszym św., pokrzepiaj go w strasznej nocy, co go otacza (s. 228, w. 12-16 d.);

69 AGAD, WKC, sygn. 36: PP 1885, nr 11 z 14 marca, k. 37 v. 
— dokonywaniu właściwych wyborów politycznych, na przykład:

Świętą wojnę bożą musim za dni naszych toczyć z szczególną żarliwością przy rozmaitych wyborach do sejmu, do dozorów kościelnych, szkolnych, komunalnych, słowem do wszystkich miejsc i urzędów wpływowych. Wszystkie one jawne i skryte prześladowania religji, wszystkie one pokrzywdzenia naszej św. Wiary, na które się żalimy, mają źródło w wyborach złych, niesumiennych (s. 269, w. 9-15 g.);

— zapisywaniu się do rozmaitych stowarzyszeń i bractw walczących z ,jarzmem pogaństwa i kacerstwa", a także ich wspieraniu:

np. do stowarzyszenia św. Bonifacego, którego zadaniem jest bronienie i rozszerzanie wiary w stronach protestanckich; do stowarzyszenia św. Franciszka Xawerego, którego zadaniem jest wspierać Misyjonarzy, co z narażeniem życia swego w krajach pogańskich zatykają krzyż Chrystusowy [...]. Są inne jeszcze bractwa i stowarzyszenia: Stowarzyszenie Dzieciatka Jezus (w Krakowie), Rozkrzewienia Wiary, św. Józefata itd. itd. (s. 270, w. 10-18 d.);

— poświęcaniu się dla wiary i Jezusa, dla którego „słodko naigrywanym być”:

Jeżeli będzie potrzeba dla sprawiedliwości pójść do więzienia, wszystko mienie utracić, kraj ojczysty porzucić, a może i głowę pod topór dać; niechże tak będzie, jeżeli taka wola boża w niezbadanych wyrokach boskich (s. 277, w. 1-3 d.-s. 278 w. 1-2 g.).

W pozostałych fragmentach pojawiały się wątki, na które zwracałem uwagę już wcześniej, a więc: wrogów Kościoła katolickiego, którzy wyginą „biorąc ze sobą do grobu hańbę, żeście w zaślepieniu swojim naprzeciw Bogu nieśmiertelnemu kusili się wojować" (s. 290, w. 16-18 g., zob. też s. 354, w. 20-21 d.); dowodów na to, że „Prawdziwym więc Kościołem Chrystusowym, [...] jest Kościół rzymsko-katolicki, w którym my z łaski bożej żyjemy" (s. 334, w. 11-13 d., zob. też s. 350, w. 1-4 g.), a reszta to sekty; wreszcie roli papieża, którego „niewierni, heretycy i bezbożni nienawidzą, spotwarzają i jak tylko mogą prześladują" (s. 336, w. $6-8$ d.).

Zmienne były losy krakowskiej „Warowni Krzyża”, pisma stowarzyszenia o tej samej nazwie, założonego przez Antoniego Zygmunta Helcla. Co prawda wydane w 1870 roku numery 3 i 4 tego kwartalnika cenzura zatrzymała, ale numer 2 dopuściła do obiegu w całości, a numer 1 z tego samego roku — warunkowo, kwestionując w nim tylko niespełna cztery strony (od w. 20 g. na s. 75 do w. 10 g. na s. 78). Był to fragment działu „Kronika polityczna”. Autor występował w nim przeciwko polskim „katolikom liberalnym”, zarzucając „teoryom szkoły” Józefa I. Kraszewskiego zionącym „nienawiścią do Rzymu” i uderzającym „na katolicyzm pod nazwą ultramontanizmu", czasopismom w rodzaju (krakowskiego) „Kraju”, „Gazety Narodowej”, Dziennika Polskiego” i „Dziennika Lwowskiego”, w których „cynizm łączy się z [...] grubą niedorzecznością”, że „,ich praca tak usilna nad zerwaniem węzłów Polski z Rzymem spotyka się na jednej linii z wszystkimi usiłowaniami Rosyi oderwania kościoła Polskiego od Rzymu" (s. 75, w. 18-21 d.). Także 
kiedy w Rosyi prześladowanie kościoła się wzmaga w Austryi nieprzestaje duch judaizmu pod pozorem liberalizmu minować i podkopywać wiary. Duch ten, który ktoś nazwał neopogańskim wprowadza jakiś rozkład moralny w schorzały organizm państwowy i zagraża zgangregowaniem całego ciała (s. 77, w. 9-13 d.).

Podobnie było w wypadku krakowskiego „Przeglądu Miesięcznego”. I w tym wypadku podjęto tylko dwie próby importu: obie w 1875 roku, przy czym dwa numery (3 i 8) cenzura dopuściła do obiegu w całości, jeden (7) - warunkowo, i także jeden (6) zatrzymała. W numerze 7 zakwestionowała na s. 145-150 tekst Ignacego Skrochowskiego $Z$ wystawy obrazów (Iwan Groźny Matejki). Największe wątpliwości budził niewątpliwie opis namalowanej sceny, z którego — z braku miejsca — przytaczam tylko niewielkie fragmenty:

z cerkwi drewnianej [...] wychodzi jakby procesya, wiodąca skazanego na śmierć bojara szlachetnej postawy [...]. Na czele pochodu dwóch Opryczników z owego legionu wcielonych szatanów ślepo posłusznych Iwanowi, który sobie on sam uformował, na postrach i wyniszczenie „ziemskich” to jest wszystkiego co było wówczas w Moskwie szlachetniejszego... [...] głowa Iwana i wzrok jego zwracają się jeszcze w kierunku pochodu, z dziwnym wyrazem grozy czy przestrachu. [...] jest to symptom powtarzający się u wszystkich okrutników dawnej i nowej ery, że choć przywykli brnąć we krwi bez pamięci, z szatańską nawet rozkoszą, czasem byle czego się lękają [...] (s. 148, w. 12-20 g. i 10-11 d.; s. 149, w. 2-5 g.).

Tę samą skalę i podobny efekt miały wcześniejsze zabiegi mające na celu wprowadzenie do obiegu lwowskiego „Światła Zagrobowego. Dziennika spirytystycznego poświęconego badaniom psychologicznym”. Spośród sprowadzonych (w 1869 roku i prawdopodobnie rok później) pięciu numerów tego miesięcznika dwa (R. 1, nr 4 i 5) oraz dodatek nr 1 zatytułowany „Fejleton[!] Spirytystyczny”70 zatrzymano, pozostałe (R. 1, nr 1-3) dopuszczono do obrotu.

Spośród rozpatrywanych w latach 1886-1888 17 zeszytów lwowskiego „Przeglądu Społecznego" zatrzymano aż 16 (R. 1, z. 1-6; R. 2, z. 7-12; R. 3, z. 1-2, 4-5), a tylko jeden (R. 3, z. 3) dopuszczono warunkowo, kwestionując w nim s. 275-287, na których opublikowano tekst Z Ukrainy. Zawierał on ostrą krytykę: stosunku petersburskiego „Kraju” do sytuacji w „całym kraju zabranym (pó1nocno i południowozachodnim)", polityki Rosji na tych ziemiach, a także postaw znacznej części zamieszkujących je Polaków. Nieco zawiły tok rozumowania anonimowego autora uporządkować można następująco:

Przyzwyczaić naród polski do patrzenia na kraj zabrany, jak na łup ofiary koniecznej na ołtarzu „starszego brata” w słowiańszczyźnie, by następnie sprawosławić go i zmoskalić, to stała dążność Rosji od pierwszego rozbioru aż do dni naszych. [...] Czynowniki, popi, aferzyści całego rozległego państwa ostatnie marzenie swe zasadzają na tem, by na wysłudze rządowi dojść do łaski nabycia jego środkami mienia w kraju zabranym (s. 280, w. 21-24 g., 16-19 d.).

${ }^{70}$ Zawierał on początek powieści Kajetana Węgierskiego Ksiązęcy żart. 
„System obrusienia” jako organiczną zasadę, wprowadził rząd w r. 1865 [...] Zubożyć, ociemnić i utrzymać w stałej agonji wymierania cały zachód państwa jest to przykuć cały zachód do pnia państwowego, według tej nauki. [...]

Uczuciu sprawiedliwości moskala stanie się wkrótce zadość: niebawem i Królestwo stanie się jak wszyscy, zarówno ubogie i nieszczęśliwe (s. 282, w. 5, 12-15 g., 7-9 d.).

\section{Niestety}

Z odjęciem panowania nad poddanymi szlachta, ziemianie [...]. Zwracają oczy swe ku Rosji, ku rządowi; jak kania deszczu wyczekują łask, zmiany systemu rządzenia i obojętni na wszystko i dla wszystkich, tracą dobra jedne po drugich (s. 277, w. 10-13 g.). 24 d.).

Polska, lud, praca społeczna i tym podobne nie wnoszą się do tych gronek [...] (s. 278, w. $23-$

obywatelstwo kresowe - to dzieci z umysłów, a zera z siły społecznej, albo i coś gorszego jeszcze (s. 279 , w. $14-15$ d.).

\section{Niewątpliwie więc to}

kraj zabrany głównym ma być przedmiotem uwagi „Kraju”, a przynajmniej, że interesa jego w tej to gazecie znaleść powinny naturalny swój organ [...] Mówili rosjanie [wydając zgodę na owo pismo]: niechaj się dowiemy, co polacy myślą. Czegoż się dowiedzieli, gdy sami polacy dotychczas nie wiedzą co „Kraj” o nich myśli? Kim być mają: polakami w kraju zabranym, czy rosjanami „polskiego pochodzenia”? (s. 280, w. 4-11 g.).

Teraz już nawet żyd nie staje się Polakiem, a mieszczanin i chłop wątpi, czy się godzi Polakiem nazwać. Oto, dokąd nas bezprogramowość doprowadziła (s. 286, w. 10-12 d.).

Te programaty: organicznej pracy, obrony bytu, pojednania się, nic wspólnego nie mają z narodem [...], żaden też nie jest w stanie przeniknąć do duszy narodu (s. 287, w. 13-16 g.).

Zmienne były też losy ponawianych co kilka lat $(1873,1875,1881,1882)$ prób importu „Przeglądu Lwowskiego”. Za pierwszym razem sprowadzony numer (R. 3, z. 3) dopuszczono warunkowo, następnym razem pięć innych zatrzymano (R. 5, z. 17-18 i 20-22), a w kolejnych latach po jednym numerze dopuszczano do obiegu w całości (R. 11, z. 10; R. 12, z. 8), a po jednym (R. 11, z. 9; R. 12, z. 7) - warunkowo.

W 1873 roku zastrzeżenia dotyczyły tylko jednej strony, a tam prawdopodobnie znajdującego się w dziale „Kronika” tekstu polemizującego z redakcjami dzienników „liberalnego i rewolucyjnego ustroju”, które krytycznie zareagowały na „pominięcie [przez papieża] w ostatniej Allokucyi [problemów] Kościoła w Polsce pod rządem rosyjskim". Znalazły się w nim między innymi takie sformułowania, jak:

Zapomniano naraz o wszystkiem, co kiedybądź Pius IX zrobił dla naszej biednej Ojczyzny, zapomnieli jak sam jeden gromił prześladowcę Kościoła, jak wobec całego świata piętnował północnego mocarza, jak mu wyrzucał [...] popełnione na Polskim Narodzie gwałty [...]. My znaliśmy od roku przyczynę milczenia Ojca świętego. Błagano o to Papieża, prosiły osoby, którym u nas 
sprawa Wiary świętej najwięcej na sercu leży, ci co więzieniem i wygnaniem zaświadczają wierność swoją Kościołowi i wierność Ojczyźnie (s. 244, w. 20-26 g., w. 4-8 d.).

W zeszycie 9 z 1881 roku zakwestionowano dwa fragmenty o łącznej objętości 12 stron. Pierwszy z nich to, podpisany kryptonimem L., tekst $Z$ ziemi wygnania [cz. 1]. Autor omawiał w nim — oparte na papierach pozostałych po wieloletniej opiekunce zesłańców Róży Sobańskiej z d. Łubieńskiej — „opowiadanie” Z Syberyi ${ }^{71}$, wspominając o tym, że „Piękne ślady jej cnotliwej i dobroczynnej działalności przechowały się w aktach [...] archiwum sybirskiego, $\mathrm{w}$ tych księgach miłosierdzia, prawdziwie złotych księgach pielgrzymstwa polskiego [...]" (s. 506, w. 10-13 g.), które zawierają też „alfabetyczny spis wygnańców, z dokładnym adresem, opisem ich potrzeb, charakterystyką i biograficznymi wiadomościami" (s. 507, w. 2-4 g.). Pisał też, że „Rząd z zaciekłością prześladował wszelkie objawy ludzkości, okazywane wygnańcom przez zwierzchników” (ibidem, w. 2-3 d.) oraz że „Osobna księga, poświęcona księżom-unitom, pełna wzruszających epizodów, przypomina nam czasem pierwsze wieki chrześcijaństwa wraz ze strasznemi prześladowaniami ówczesnemi” (s. 508, w. 10-12 g.), ilustrując to przykładami.

Tekst drugi to siódmy fragment, drukowanej od numeru 3 z tegoż roku, powieści nieznanego autorstwa Semen Korniejuk. Jej akcja rozgrywała się we wsi na Podlasiu, dwa lata po upadku powstania styczniowego. W tekście znalazły się nie tylko liczne wzmianki o tym wydarzeniu, ale także informacje na temat pogarszającej się sytuacji unitów. Oto fragment rozmowy między młodym Rusinem Hryckiem a obiektem jego uczuć — córką tytułowego sołtysa, Oksenią, która kochała jednak pochodzącego z Krakowa Stanisława Górskiego:

Stanisław [...] to Lach przebrany i gorzej jeszcze jak Lach, bo kiedy dobry nasz cesarz z poddaństwa nas oswabadzał, on z końca świata przyleciał i związawszy się z tutejszymi bił się, żeby pańszczyznę obronić.

Dziewczyna zadrżała. [...] jakim prawem możesz utrzymywać, że ci, którzy po tych lasach w nędzy, we krwi i ranach chodzili, pańszczyznę obronić chcieli? [...] przyjdzie taki czas, że tak samo jak oni i my się kiedyś damy porąbać na kawałki, i że tutaj oni są biedni, cierpiący i święci, a tylko ten cesarz, którego ty i tobie podobni dobrym nazywacie, jest rozbójnik prawdziwy, bo zamiast przygarnąć do siebie dzieci swoje, on im wzajemnie zabijać i mordować się każe (s. 528, w. $1-5$ d.; s. 529 , w. $1,8-10,15-20$ g.).

Jeśli chodzi o problem unitów, to narrator obszernie przypominał kolejne kroki władzy: zakaz wygłaszania kazań po rusińsku, śpiewania „godzinek, różańca i innych pobożnych pieśni polskich”, odprawiania „księżom łacińskim nabożeństwa w cerkwiach, a unickim bywania w kościele", obchodzenia uroczystości Bożego Ciała, używania w cerkwi organów. Tak więc

71 K., Z Syberyi. Z papierów po Róży Sobańskiej, „Przegląd Polski” 15, 1881, t. 59, s. 406-455. Część 2 zawierała omówienie korespondencji Bronisława Zaleskiego do Sobańskiej, opublikowanej tamże przez tegoż K. pod tytułem Z Orenburga. 
Ów oswobodziciel łaskawy, ów potężny, a zarazem miłosierny car, zaczął pokazywać swoje pazury. [...] Zwodnicze łaski powoli z oczu pozornemi dobrodziejstwami otumanionych opadać zaczęły [...].

[Także Stanisław] widział, jak wróg coraz nowe wymyśla sposoby, byleby tylko dzieło zniszczenia i wynarodowienia przyprowadzić do skutku (s. 532, w. 11-15 g., 2-4 d.).

Wreszcie w zeszycie 7 z 1882 roku cenzura nakazała usunąć ostatni fragment działu „Kronika” (s. 435-436), a więc punkty III-V. Pierwszy z nich dotyczył „zaprowadzenia” w zakładach naukowych w Królestwie Polskim kalendarza juliańskiego, co jest

objawem jawnej walki prawosławia z katolicyzmem [...] pierwszym krokiem na drodze zrównania Kongresówki pod względem religijnym z krajem zachodnim. [...] Najstraszniejszy to ucisk, bo łamie zwyczaje, tradycye, poczucia i obyczaje. Takie jest postępowanie rządu rosyjskiego, który w obłędzie walki plemiennej nie widzi, że stoi nad przepaścią. Tak postępuje ,uczony górnik" [Aleksandr Lwowicz] Apuchtin, „prześwięty” [arcybiskup chełmsko-warszawski] Leoncyusz i filar prawosławia, wielki oberprokurator synodu [Konstantin Pietrowicz] Pobiedonoscew w chwili, gdy postępowa część społeczeństwa rosyjskiego upatruje w Polsce ostatnią kotwicę zbawiania dla rozpadającej się Rossyi (s. 435, w. 14-15, 17-18, 23-29 g.).

\section{Punkt następny poświęcony był informacji, iż}

Z ziemi wygnania, z głębi Rossyi i Syberyi, gdzie Najprzewielebniejsi biskupi i kapłani pędzą ciężkie chwile niewoli i oddalenia dochodzi [...] wiadomość, że niektórym kapłanom naszym pozwolono wrócić z Syberyi i osiedlić się w każdej innej z gubernij rosyjskich, z wyjątkiem ziem polskich. [...] [Niestety jednocześnie] ustaje wypłata dotychczasowej pensyi, przyznanej wygnańcom w kwocie 6 rubli na miesiąc, a ponieważ i podróż odbywa się na koszt „ułaskawionych”, przeto nieszczęśliwi kapłani nasi po większej części nie mogą korzystać z wolności zbliżenia się do stron ojczystych (s. 435 , w. $6-9,14-17$ d.).

\section{Wreszcie w punkcie ostatnim autor podzielił się spostrzeżeniem, że}

W naszym wieku, kiedy tyle się zbrodni dokonywa, a nawet zamachów na ukoronowane głowy (jak cesarzów, królów, królowych i prezydentów republik), godnym uwagi jest fakt, iż żadnego nie można wykazać zamachu na osobę Papieża rzymskiego. [...] Nie co innego, ale katolicyzm to najsilniejszy środek przeciw królobójstwu" (s. 436, w. 1-4, 24-25 g.).

Czasopism, których nigdy nie dotknęła ingerencja cenzury, było niewiele, gdyż tylko 21. Co jednak dziwne, większość z nich importowano tylko raz. Były to (w kolejności chronologicznej): krakowska „Gazeta Przemysłowa” (numery 1-3 z 1866 roku) ${ }^{72}$, lwowski „Słowianin” (numery 1-4 z 1868 roku), lwowska „Gazeta Narodowa” (numer 44 z 1874 roku), lwowski „Pamiętnik Literacki” (numery 1-29 z 1850

72 Jeśli nie zamieściłem dodatkowej wiadomości, znaczy to, że wymienione numery rozpatrywano w roku wydania. 
roku; w 1876 roku), krakowski „Przegląd Sprawy Wschodniej” (numer 1 z 1877 roku), „Dziennik Poznański”, (numery 130, 133, 135 z 1879 roku), lwowski „Kosmos” (numery 1 i 4 z 1879 roku), wiedeński „Meteor” (numer 1 z 1879 roku), wiedeński „Północny Meteor” (numer 2 z 1879 roku), poznański „Pasiecznik” (R. 1-3 z lat 1883-1885; w 1886 roku), krakowski „Świat” (numery 1, 2 i 4 z 1888 roku), poznańska „Muzyka Kościelna” (numery 1-12 z 1890 roku), krakowski „Przewodnik Praktyczny” (R. 1 z 1891 roku; w 1892 roku) ${ }^{73}$, wiedeńskie „Romanse Illustrowane Wszystkich Narodów” (rocznik 1881; w 1895 roku), „Dziennik IX Zjazdu Lekarzy i Przyrodników Polskich w Krakowie (numery 1-5, czyli cały rocznik 1900), krakowskie „Wiadomości Społeczno-Ekonomiczne” (R. 1, numery 1-3, 5 z 1903 roku).

Przykładów kontynuowania udanego importu było zaledwie kilka. Dwukrotnie sprowadzono: lwowskiego „Prawnika” (numery 1-52 z 1874 roku i numery 6-19 z 1875 roku), poznański „Ruch Społeczno-Ekonomiczny” (R. 1, numery 1-6 z 1875 roku i 7-24 z 1876 roku — w 1877 roku; R. 2, numer 24 z 1877 roku; R. 3, numery $1-6$ z 1877 roku oraz numery $7-10,15$ z 1878 roku - w 1878 roku), lwowski „Przegląd Archeologiczny” (z. 3 z 1882 roku i z. 2 z 1883 roku), krakowski „Okólnik” (numer 42 z 1899 roku i numer 72 z 1904 roku), a czterokrotnie krakowskiego „Herolda (w latach 1897-1899 sprowadzono kolejno: R. 1, z. 1-2; R. 1, z. 3-4 i R. 2, z. 1; cały rocznik 3).

4

Zaprezentowane $\mathrm{w}$ tekście przykłady uzasadnień negatywnych decyzji cenzorskich oraz przytoczone fragmenty tekstów czasopiśmienniczych kwestionowanych przez urzędników aparatu kontroli potwierdzają spostrzeżenia i konkluzje formułowane wcześniej zarówno przeze mnie, jak i przez Małgorzatę Rowicką na podstawie analizy polityki cenzuralnej władz w stosunku do importowanych książek $^{74}$.

73 Sprowadzono wydanie drugie pisma, więc być może jego treść była dostosowana do wymogów cenzuralnych obowiązujących w Cesarstwie.

74 J. Kostecki, Warianty wydawnicze jako reakcja na ingerencje...; idem, Carska cenzura obyczajowa w drugiej połowie XIX wieku a możliwość opisu rzeczywistości, [w:] Realiści, realizm, realność. W stulecie śmierci Bolesława Prusa, pod. red. E. Paczoskiej, B. Szleszyńskiego, D.M. Osińskiego, Warszawa 2013, s. 65-82; idem, Rosyjska praktyka kontroli piśmiennictwa...; idem, Cenzura rosyjska wobec importu polskojęzycznych publikacji z terenu Prus Zachodnich w latach 1865-1904, [w:] W'swiecie bibliologii i informatologii, pod red. M. Fedorowicz-Kruszewskiej, M. Cyrklaff-Gorczycy, T. Kruszewskiego, Toruń 2019, s. 129-146; J. Kostecki, M. Rowicka, „Dozwoleno s iskluczenijem”. Ingerencje rosyjskiej cenzury zagranicznej w latach 1869-1900, [w:] Piśmiennictwo — systemy kontroli..., s. 269-297; idem, Cenzura rosyjska wobec twórczości Adama Mickiewicza w latach 1865-1904, „Rocznik Biblioteki Narodowej” 35, 2003, s. 283-294; idem, Import do zaboru rosyjskiego ksiażek literackich adresowanych do młodego odbiorcy i ich 
Po prostu, najbardziej ogólne zasady cenzurowania zarówno produkcji miejscowej, jak i importowanej, tak czasopism jak i książek — były wspólne. W wypadku WKC jednolitość tę wzmacniał dodatkowo fakt, że był to - jak już wspomniałem - urząd wielofunkcyjny. Ci sami urzędnicy zajmowali się kontrolowaniem publikacji rozmaitego typu, choć oczywiście w obrębie zespołu istniał podział obowiązków będący następstwem znajomości przez pracowników określonych języków obcych, a także ich zróżnicowanych kompetencji dziedzinowych. Nie znaczy to oczywiście, że polityka cenzuralna była niezmienna i do końca przewidywalna, a podejmowane decyzje były zawsze konsekwentne ${ }^{75}$. Jak bowiem wspominał wieloletni cenzor, a potem prezes WKC, cytowany już Emmausski,

w swoich służbowych obowiązkach nie mogliśmy się kierować tylko kodeksem. Stale musieliśmy brać pod uwagę ogromną liczbę okólników Głównego Urzędu do spraw Druku, którymi zasypywano nas z Petersburga, pamiętać o różnych poleceniach generał-gubernatorów i uwzględniać tak zwane „okoliczności miejscowe”. Czasem właśnie dlatego trzeba było zupełnie ignorować przepisy i kierować się własnym uznaniem, albo jak mawiał [Nikołaj Iwanowicz] Ryżow, „mieć nosa" $[\ldots]^{76}$.

cenzurowanie w latach 1865-1904, „Sztuka Edycji. Studia Tekstologiczne i Edytorskie” 2020, $\mathrm{nr}$ 2. Edytorstwo literatury dla dzieci i mlodzieży, pod. red. M. Lutomierskiego, s. 117-135; M. Rowicka, O neurotycznym cenzorze, przebiegtym wydawcy i manipulowanym czytelniku, czyli „Pan Tadeusz" w Warszawie w okresie zaborów, Warszawa 2004; eadem, Spokojny sen Senatora, czyli o cenzurowaniu przez carat Mickiewiczowskich „Dziadów” części trzeciej, [w:] Niewygodne dla władzy..., s. 83-102; eadem, Wydawnicze i cenzuralne losy twórczości Adama Mickiewicza...; eadem, ,,Beniowskiego" potyczki z cenzura rosyjska w latach 1865-1914, [w:] Literatura w granicach prawa..., s. 87-107; eadem, Mikołowskie edycje utworów wielkich romantyków polskich w latach 1898-1912, „Bibliotheca Nostra. Śląski kwartalnik naukowy” 4, 2016, s. 27-49; eadem, Mikołowskie wydania „Pism” Zygmunta Krasińskiego a cenzura carska, [w:] Zygmunt Krasiński. „Varia” tekstowe i tekstologiczne, pod red. M. Strzyżewskiego, Toruń 2016, s. 71-92; eadem, Wydawnicze i cenzuralne losy twórczości Juliusza Słowackiego w okresie zaborów (w oprac. red.); M. Rowicka, J. Kostecki, Carska cenzura zagraniczna wobec syntez dziejów literatury polskiej w latach 1865-1914, [w:] Historie literatury polskiej 1864-1914, pod red. U. Kowalczuk, Ł. Książyka, Warszawa 2015, s. 13-31.

75 Wiele cennych i trafnych uwag na ten temat sformułował Henryk Bałabuch (Nie tylko cenzura. Prasa prowincjonalna Królestwa Polskiego $w$ rosyjskim systemie prasowym $w$ latach 1865-1914, Lublin 2001, zwłaszcza s. 23, 233).

76 Ch. Emmausski, Ze wspomnień warszawskiego cenzora, [w:] Świat pod kontrola. Wybór materiałów z archiwum cenzury rosyjskiej w Warszawie, wybór, przekł. i oprac. M. Prussak, Warszawa 1994, s. 24. Na temat wspomnianych okólników zob. [Foote] I.P. Fut, Cirkulâry cenzurnogo vedomstva 1865-1905 gg., [w:] Cenzura v Rossii. Istoriâ i sovremennost': sbornik naučnyh trudov, vyp. 3, redkol. W.R. Firsow i dr., sost. i nauč. red. M.A. Benina i dr., Sankt-Peterburg 2006, s. 106-132. Najobfitsze zbiory rozporządzeń różnych władz zob. Periodičeskaâ pečat' $i$ cenzura Rossijskoj imperii v 1865-1905 gg. Sistema administrativnyh vzyskanij: Spravočnoe izdanie, sost. i avtor vstupitel'noj stat'i N.G. Patruševa, Sankt-Peterburg 2011; Cirkulâry cenzurnogo vedomstva Rossijskoj imperii. Sbornik dokumentov, sost. N.G. Patruševa, I.P. [Foote] Fut, Sankt-Peterburg 
Choć autor/zy kryjący się pod pseudonimem Baronowa XYZ celnie pisali w drugiej połowie lat 80 ., że

Stałych zasad i regulaminu nie ma, chociaż jest osobna ustawa cenzuralna. [...] Zasadniczo więc cenzura w Rosyi jest władzą na wskroś dyskrecyonalną, żadnemi przepisami nie ujętą, żadnym prawom niepodlegającą. Cenzorowi wolno jest wszystkiego się domyślać i we wszystkiem dopatrywać się uchybienia [...]. Ta zasadnicza dyskrecyonalność cenzury wytwarza jej niejednostajność $[\ldots]^{77}$,

to jednak - przynajmniej jeśli weźmiemy pod uwagę typy kwestionowanych treści — widoczne były pewne dominanty. Większość negatywnych decyzji urzędników miała swe źródło w dwóch pierwszych (spośród czterech) punktów artykułu 4 ustawy cenzuralnej:

Utwory piśmiennictwa, nauki i sztuki podlegają zakazowi cenzury na podstawie przepisów tej ustawy: a) gdy zawierają cokolwiek zmierzającego do podważenia nauk Cerkwi prawosławnej, jej tradycji i obrzędów, lub w ogóle prawd i dogmatów wiary chrześcijańskiej; b) gdy zawierają cokolwiek naruszającego nietykalność Najwyższej Władzy Samowładnej lub szacunek dla Domu Cesarskiego i cokolwiek sprzecznego z zasadniczymi przepisami państwa $[\ldots]^{78}$.

To z uwagi na przytoczony punkt ,a" kwestionowano po pierwsze — pojęcia w rodzaju „schizma” czy „zbłądzenie”, używane na określenie prawosławia, a także konstatacje o podporządkowaniu Cerkwi władzy świeckiej; po drugie — tezy o tym, że katolicyzm to jedyna wiara prawdziwa, święta, powszechna, apostolska, i że tylko papież zapewnia religii niezależność i trwałość; po trzecie — wszelkie informacje o innych instytucjach Kościoła katolickiego, zwłaszcza o działalności zakonu jezuitów oraz towarzystw i bractw religijnych, a także o obowiązkach katolików; po czwarte - teksty dotyczące represjonowania Kościoła katolickiego w Rosji; po piąte — wzmianki na temat unitów, ich prześladowań i prób przeciągnięcia wiernych na prawosławie.

Natomiast punkt ,b" uzasadniał usuwanie po pierwsze — obraźliwych określeń w stosunku do Rosjan i ich działań, typu: Moskale, dzicz mongolska, barbarzyńska samowola; po drugie - niepochlebnych informacji i opinii na temat zarówno dawnych (Iwana Groźnego, Katarzyny II), jak i współczesnych władców Rosji (zwłaszcza Aleksandra III), w tym demonstracyjnego braku współczucia dla ofiary zamachu, Aleksandra II; po trzecie — krytycznych analiz dotyczących

2016. W obu publikacjach znajdują się jednak niemal wyłącznie dokumenty dotyczące działalności cenzury wewnętrznej i druków w języku rosyjskim.

77 [A. Zaleski?; K. Górski, J. Górska, S. Koźmian?] Baronowa XYZ, Towarzystwo warszawskie. Listy do przyjaciółki, wyd. 2 przejrzane, poprawione i znacznie rozszerzone, T. 2, Kraków 1889, s. 90-91.

78 Ustav o cenzure..., s. 1. Przepisy cenzuralne mogące mieć zastosowanie przy kontrolowaniu publikacji importowanych, w tym także ich zmiany, omawiam dokładnie w pracy Trudny proces przenikania..., s. 37-43. Należy zauważyć, że inne, odnoszące się do spraw szczegółowych, przepisy ustawy w zasadzie nie wprowadzały wiele nowego w stosunku do zacytowanych norm ogólnych. 
istoty ustroju Rosji, głównie despotyzmu, centralizacji, braku zasad etycznych (charakterystycznych na przykład dla działań w guberniach zachodnich), pogardy dla społeczeństwa, co wobec zgnilizny moralnej samej ludności doprowadziło do tego, że Rosja stała się ojczyzną nihilizmu; po czwarte — krytycznych sformułowań odnoszących się do wysokich urzędników carskich (na przykład Potiomkina, Sipiagina, generała-gubernatora warszawskiego); po piąte - informacji na temat złej sytuacji gospodarczej Rosji i obojętności władz na przykład wobec panującego głodu; po szóste - uwag na temat panującego terroru politycznego, w tym opowieści o losach zesłańców syberyjskich; po siódme — ambicji Rosji do całkowitego podporządkowania sobie narodów słowiańskich, a także Finlandii.

Pojemne sformułowanie o konieczności eliminowania z obiegu wszystkiego, co w jakikolwiek sposób sprzeczne jest z „zasadniczymi przepisami państwa”, usprawiedliwiało też kwestionowanie wszelkich tekstów dotyczących narodowych aspiracji Polaków, które traktowano jako przejaw tendencji odśrodkowych i separatystycznych, osłabiających jedność imperium. W tym kontekście zwracano uwagę na polskopatriotyczną tendencję wypowiedzi, wojujący polonizm, dążenia do odrodzenia państwowości, nienawistny stosunek do Rosji i jej rządu, a także pogardliwe traktowanie zwyczajów rosyjskich. Eliminowano w związku z tym: po pierwsze - opinie na temat wyższości i posłannictwa narodu polskiego oraz termin „ojczyzna”; po drugie - odniesienia do Polski przedrozbiorowej; po trzecie — wzmianki odnoszące się do powstań narodowych; po czwarte — informacje o tym, co składa się na świadomość narodową Polaków (tradycja, duma ze wspaniałej historii, zabytki, wielcy ludzie); po piąte — dane na temat instytucji i działań służących budowaniu uczuć patriotycznych i sprzyjających samoorganizacji społeczeństwa (szkolnictwo polskie, przemyt wydawnictw, działalność oświatowa wśród ludu); po szóste - wezwania do potępiania zdrajców, piętnowanie kolaboracji z wrogiem; po siódme - propagowanie zachowań godnościowych, nieugiętych; po ósme - teksty budzące nadzieję na rychły kres absolutyzmu w Rosji i odzyskanie wolności przez wszystkie narody przez nią prześladowane.

To samo sformułowanie, a zwłaszcza jego uszczegółowienia w artykułach 95 i $96^{79}$, stanowiły podstawę eliminowania informacji na temat walki robotników o prawa pracownicze, wezwań do poprawy doli chłopów, wypowiedzi wyrażających nadzieję na wzmocnienie ruchu rewolucyjnego w Rosji i w ogóle zbliżanie się wybuchu rewolucji społecznej ${ }^{80}$.

79 Pierwszy dotyczył eliminowania „dzieł i artykułów przedstawiających szkodliwe teorie socjalizmu i komunizmu, zmierzające do zachwiania lub obalenia istniejącego porządku i wprowadzenia anarchii”, drugi - tych, „w których wzbudza się niechęć i nienawiść jednego stanu do drugiego", oraz tych, „w których znajdują się obraźliwe szyderstwa w stosunku do całych grup społecznych lub urzędów państwowych i społecznych" (Ustaw o cenzure..., s. 15).

80 Podobne tematy i problemy kwestionowano także w prasie miejscowej — M. Tobera, Cenzura czasopism w Królestwie Polskim na przełomie XIX i XX wieku, „Przegląd Historyczny” 
$* * *$

Zaprezentowany tekst przedstawia niewątpliwie podstawowe zasady funkcjonowania rosyjskiego aparatu kontroli prasy oraz zarysowuje granice wolności słowa obowiązujące w zaborze rosyjskim w badanym okresie. Pokazuje też niektóre sposoby radzenia sobie przez importerów z istniejącymi ograniczeniami. Zawiera też sporo efektownych przykładów sformułowań, którymi można się posłużyć, analizując inne obszary ówczesnej rzeczywistości społecznej. Stawia też jednak kilka pytań, na które nie potrafię odpowiedzieć w sposób mnie satysfakcjonujący. Pierwsze dotyczy tego, dlaczego - choć zdarzały się przecież udane próby importu - próbowano sprowadzać do Królestwa tak małą liczbę tytułów? Może po prostu nie było zapotrzebowania na zakordonową ofertę prasową, może ówczesnej publiczności wystarczała oferta miejscowa, a nieliczne elity zaspokajały swe potrzeby informacyjne w obiegu nielegalnym? Pytanie drugie odnosi się do problemów źródłowych: czy dalsze poszukiwania materiałowe, przede wszystkim w Petersburgu, wzbogaciłyby przedstawiony obraz, czy tylko dodatkowo je potwierdziły? Czy pozwoliłyby na przykład odsłonić mechanizmy podejmowania decyzji o pozbawieniu debitu komunikacyjnego najważniejszych dzienników i czasopism? Kto i kiedy je podejmował? Przecież te tytuły, o których pisałem, w większości funkcjonowały na drugim planie, głównie w obiegach zamkniętych. W końcu pytanie trzecie: czy koncentrując się tylko na zakazach cenzuralnych, nie otrzymujemy jednostronnego obrazu rzeczywistości? Czy w ogóle - mając przy tym świadomość ciągłych zmian w polityce kontrolnej — można wyznaczyć granice pomiędzy tym, co było wolno, a tym, co było niedopuszczalne? Nawiasem mówiąc, może władzom po trosze o to chodziło. Oczywiście nie miały one na myśli ani autora, ani czytelników tego tekstu.

\section{BIBLIOGRAFIA}

Alfavitnyj katalog knigam na pol'skom i žmudskom âzykah, zapreŝennym vpolne i pozvolennym s isklûčeniâmi, s 1830 po iûn' mesâc 1869 goda vklûčitel'no, Sankt-Peterburg 1869.

Bałabuch H., Nie tylko cenzura. Prasa prowincjonalna Królestwa Polskiego w rosyjskim systemie prasowym w latach 1865-1914, Lublin 2001.

Brandes G.M.C., Polska, przeł. Z. Poznański, Lwów 1898.

Cenzory Rossijskoj imperii konec XVIII-načalo XX veka. Biobibliografičeskij spravočnik, red. koll. V.R. Firsov [et al.], avt. koll. O.Û. Abakumov [et al.], Sankt-Peterburg 2013.

1989, nr 1 (80), s. 41-67, choć w tym wypadku — z powodu braku materiałów — trudno o tak szczegółową dokumentację jak w wypadku periodyków importowanych. 
Cirkulâry cenzurnogo vedomstva Rossijskoj imperii. Sbornik dokumentov, sost. N.G. Patruševa, I.P. [Foote] Fut, Sankt-Peterburg 2016.

Dopolnitel'nyj k ,Alfavitnomu katalogu 1869g.” spisok knig na pol'skom âzyke, zapreŝennym i pozvolennym s isklûčeniâmi s iûlâ 1869 g. po dekabr' 1876 g. vklûčitel'no, Sankt-Peterburg 1877.

Emmausski Ch., Ze wspomnień warszawskiego cenzora, [w:] Świat pod kontrola. Wybór materiatów z archiwum cenzury rosyjskiej w Warszawie, wybór, przekł. i oprac. M. Prussak, Warszawa 1994.

[Foote] Fut I.P., Cirkulâry cenzurnogo vedomstva 1865-1905 gg., [w:] Cenzura v Rossii. Istoriâ i sovremennost': sbornik naučnyh trudov, vyp. 3, redkol. W.R. Firsow i dr., sost. i nauč. red. M.A. Benina i dr., Sankt-Peterburg 2006, s. 106-132.

Izmozik V.S., Počtovaâ cenzura v Rossii do 1917 g.: oficialnaâ i tajnâ̂, [w:] Cenzura i dostup k informacii: istoriâ i sovremennost'. Tezisy dokladov meždunarodnoj naučnoj konferencii, Sankt-Peterburg, 16-18 marta 2005 g, Sankt-Peterburg 2005.

Kmiecik Z., Prasa warszawska w okresie pozytywizmu (1864-1885), Warszawa 1971.

Kostecki J., Carska cenzura obyczajowa w drugiej połowie XIX wieku a możliwość opisu rzeczywistości, [w:] Realiści, realizm, realność. W stulecie śmierci Bolesława Prusa, pod red. E. Paczoskiej, B. Szleszyńskiego, D.M. Osińskiego, Warszawa 2013, s. 65-82.

Kostecki J., Carski system cenzury zagranicznej w XIX wieku, [w:] Niewygodne dla władzy. Ograniczanie wolności słowa na ziemiach polskich w XIX i XX wieku. Zbiór studiów, pod red. D. Degen, J. Gzelli, Toruń 2010.

Kostecki J., Cenzura rosyjska wobec importu polskojęzycznych publikacji z terenu Prus Zachodnich w latach 1865-1904, [w:] W'siecie bibliologii i informatologii, pod red. M. Fedorowicz-Kruszewskiej, M. Cyrklaff-Gorczycy, T. Kruszewskiego, Toruń 2019, s. 129-146.

Kostecki J., Rosyjska praktyka kontroli piśmiennictwa - uzasadnienia negatywnych decyzji cenzorskich w 2. połowie XIX wieku. Próba typologii, [w:] Literatura w granicach prawa (XIXXX w.), pod red. K. Budrowskiej, E. Dąbrowicz, M. Lula, Warszawa 2013.

Kostecki J., Trudny proces przenikania. Carska cenzura zagraniczna wobec importu publikacji w języku polskim w latach 1865-1904, Warszawa 2011.

Kostecki J., Warianty wydawnicze jako reakcja na ingerencje cenzury rosyjskiej w II połowie XIX w., [w:] Trzy pokolenia. Pamięci Profesor Janiny Kulczyckiej-Saloni, Warszawa 1998, s. $161-170$.

Kostecki J., Warszawski Komitet Cenzury w latach 1870-1906, [w:] Ksią̇ka zawsze obecna. Prace ofiarowane Krzysztofowi Migoniowi, pod red. M. Skalskiej-Zlat, Wrocław 2010.

Kostecki J., Rowicka M., Cenzura rosyjska wobec twórczości Adama Mickiewicza w latach 18651904, „Rocznik Biblioteki Narodowej” 35, 2003, s. 283-294.

Kostecki J., Rowicka M., ,Dozwoleno s iskluczenijem”. Ingerencje rosyjskiej cenzury zagranicznej w latach 1869-1900, [w:] Piśmiennictwo - systemy kontroli - obiegi alternatywne, pod red. J. Kosteckiego, A. Brodzkiej, T. 1, Warszawa 1992, s. 269-297.

Kostecki J., Rowicka M., Granice wolności słowa w zaborze rosyjskim w latach 1865-1904. Wykaz publikacji polskojęzycznych zakwestionowanych oraz dopuszczonych do obiegu przez carska cenzurę zagraniczna, T. 1-3, Warszawa 2006.

Kostecki J., Rowicka M., Import do zaboru rosyjskiego ksiażek literackich adresowanych do mtodego odbiorcy i ich cenzurowanie w latach 1865-1904, „Sztuka Edycji. Studia Tekstologiczne i Edytorskie" (w oprac. red.).

[Krzemiński S.], Dwadzieścia pięć lat Rosyi w Polsce (1863-1898). Zarys historyczny, Lwów 1892. Ministerstvo vnutrennih děl. 1802-1902. Istoričeskij očerk, priloženie 2: počta i telegraf v XIX stoletii, Sankt-Peterburg 1901. 
Periodičeskaâ pečat' i cenzura Rossijskoj imperii v 1865-1905 gg. Sistema administrativnyh vzyskanij: Spravočnoe izdanie, sost. i avtor vstupitel'noj stat'i N.G. Patruševa, Sankt-Peterburg 2011.

Ramotowska F., Sto lat „, cenzury rządowej” pod zaborem rosyjskim (1815-1915) — podstawy normatywne, instrumenty wykonawcze, [w:] Piśmiennictwo — systemy kontroli - obiegi alternatywne, pod red. J. Kosteckiego, A. Brodzkiej, T. 1, Warszawa 1992.

Rowicka M., ,Beniowskiego” potyczki z cenzura rosyjska w latach 1865-1914, [w:] Literatura w granicach prawa (XIX-XX w.), pod red. K. Budrowskiej, E. Dąbrowicz, M. Lul, Warszawa 2013, s. 87-107.

Rowicka M., Mikołowskie edycje utworów wielkich romantyków polskich w latach 1898-1912, „Bibliotheca Nostra. Śląski kwartalnik naukowy" 4, 2016, s. 27-49.

Rowicka M., Mikołowskie wydania „Pism” Zygmunta Krasińskiego a cenzura carska, [w:] Zygmunt Krasiński. ,Varia” tekstowe i tekstologiczne, pod red. M. Strzyżewskiego, Toruń 2016, s. 71-92.

Rowicka M., O neurotycznym cenzorze, przebiegłym wydawcy i manipulowanym czytelniku, czyli „Pan Tadeusz” w Warszawie w okresie zaborów, Warszawa 2004.

Rowicka M., Spokojny sen Senatora, czyli o cenzurowaniu przez carat Mickiewiczowskich „Dziadów” części trzeciej, [w:] Niewygodne dla władzy. Ograniczanie wolności słowa na ziemiach polskich w XIXi XX wieku. Zbiór studiów, pod red. D. Degen, J. Gzelli, Toruń 2010, s. 83-102.

Rowicka M., Wydawnicze i cenzuralne losy twórczości Adama Mickiewicza w okresie zaborów, Warszawa 2014.

Rowicka M., Wydawnicze i cenzuralne losy twórczości Juliusza Stowackiego w okresie zaborów (w oprac. red.).

Rowicka M., Kostecki J., Carska cenzura zagraniczna wobec syntez dziejów literatury polskiej w latach 1865-1914, [w:] Historie literatury polskiej 1864-1914, pod red. U. Kowalczuk, Ł. Książyka, Warszawa 2015, s. 13-31.

Tobera M., Cenzura czasopism w Królestwie Polskim na przełomie XIX i XX wieku, „Przegląd Historyczny" 80, 1989, z. 1, s. 41-67.

Tobera M., Cenzura prasy w Cesarstwie Rosyjskim na przełomie XIX i XX w., [w:] Piśmiennictwo - systemy kontroli - obiegi alternatywne, pod red. J. Kosteckiego, A. Brodzkiej, T. 1, Warszawa 1992, s. 175-223.

[Wasilewski Z.] Przygodny, Warszawa wspótczesna w dwunastu obrazach, Lwów 1903.

[Zaleski A.?; Górski K., Górska J., Koźmian S.?] Baronowa XYZ, Towarzystwo warszawskie. Listy do przyjaciótki, wyd. 2, przejrzane, poprawione i znacznie rozszerzone, T. 2, Kraków 1889.

JANUSZ KOSTECKI

\section{CONTROL OF FOREIGN PERIODICALS AND POLISH PERIODICALS FROM BEYOND THE CORDON BY RUSSIAN CENSORS IN 1865-1904}

\section{Summary}

The aim of the article is to reconstruct the possibilities people living in the part of Poland annexed by Russia had to access Polish-language periodicals published outside that area. The author draws on two types of sources hitherto barely every used: monthly lists of imported publications dealt with by tsarist censors between the fall of the January Uprising and the outbreak of the 1905 Revolution, lists published by the (Central) Committee of Foreign Censorship in Saint Petersburg, 
as well as all minutes of meetings - preserved in the Archives of Historical Records in Warsaw of the Warsaw Censorship Committee from the analysed period, which contain justifications of the decisions taken by the officials with regard to various publications. In addition, the author has been able to access nearly all issues of journals censored in any way at the time and currently kept in the 23 largest Polish historical libraries. It turns out that import attempts (possible only in the case of periodicals that had not been previously proscribed) were rare and concerned only 93 titles. In the case of over a half of them censors prevented even a single issue from being circulated. Justifications of the refusals were similar to those formulated with regard to books. Most of them focused on protecting the Orthodox religion, the Imperial House, and Russia's policy. Particular attention was paid to limiting the influence of the Catholic Church and the Poles' aspirations to freedom. However, sometimes censorship was - perhaps deliberately so - inconsistent. It seems that the limited scale of import was also influenced by the limited interest in publications from beyond the cordon on the part of the local readers, who were satisfied with Warsaw publications.

KEY WORDS: tsarist foreign censorship, limits of freedom of speech — the Russian partition - 19th century, Polish-language magazines — import — Russian partition, Polish-language magazines - censorship, censoring journals - types of questioned content - censorship justifications 